\title{
A study of the water retention curve of lime-treated London Clay
}

\author{
Xiwei Zhang $^{1,2} \cdot$ Maria Mavroulidou ${ }^{2}$ Michael J. Gunn ${ }^{2}$
}

Received: 19 February 2015/Accepted: 21 December 2015/Published online: 27 January 2016

(c) The Author(s) 2016. This article is published with open access at Springerlink.com

\begin{abstract}
This paper investigates the drying and wetting soil water retention curves (SWRCs) of statically compacted lime-stabilised London Clay specimens. A series of tests were performed using the contact filter paper method, pressure plate apparatus and a suction-controlled triaxial system incorporating the axis translation technique. These investigated the water retention of the soil under different boundary and stress-state conditions and simultaneously determined the volume change in the soil during drying and wetting. Factors relevant to the lime treatment of soils, such as curing period and method (air vs. water curing), were also considered. Finally, the hysteresis of the SWRC of the chemically treated soil (for which there appears to be a lack of information in the international literature) was investigated. The results showed that the treatment with lime increased the volumetric stability but reduced the water retention ability due to a more open structure enabled by the flocculation and chemical bonding effects. Curing period and method effect appears to be small. Hysteresis was noted to some degree in all instances.
\end{abstract}

Maria Mavroulidou

mavroum@1sbu.ac.uk

Xiwei Zhang

zhangxiwei@mail.neu.edu.cn

Michael J. Gunn

gunnm@1sbu.ac.uk

1 Present Address: Key Laboratory of Ministry of Education on Safe Mining of Deep Metal Mines, Northeastern University, Shenyang 110819, Liaoning, China

2 London South Bank University, 103 Borough Road, London SE1 0AA, UK
Keywords Hysteresis - Lime stabilisation · Partially saturated soil $\cdot$ Soil water retention curve $\cdot$ Volume change

\section{List of symbols}

e $\quad$ Void ratio

$e_{\mathrm{w}} \quad$ Water void ratio, $e_{\mathrm{w}}=V_{\mathrm{w}} / V_{\mathrm{s}}$

$G_{\mathrm{s}} \quad$ Specific gravity

$s \quad$ Suction $(\mathrm{kPa})$

$S_{\mathrm{e}} \quad$ Effective degree of saturation

$s_{\mathrm{r}} \quad$ Residual suction $(\mathrm{kPa})$

$S_{\mathrm{r}} \quad$ Degree of saturation

$S_{\mathrm{r}_{\mathrm{res}}} \quad$ Residual degree of saturation

$u_{\mathrm{a}} \quad$ Air pressure

$u_{\mathrm{w}} \quad$ Pore water pressure

$\left(u_{\mathrm{a}}-u_{\mathrm{w}}\right) \quad$ Matric suction

$V_{\mathrm{w}} \quad$ Volume of water

$V_{\mathrm{s}} \quad$ Volume of solids

$w \quad$ Water content (gravimetric)

$w_{\text {norm }} \quad$ Normalised water content (gravimetric)

$\alpha, n$ and $m$ Curve-fitting parameters for the soil water retention curve (van Genuchten's model)

$\varepsilon_{\mathrm{v}} \quad$ Volumetric strain

$\theta \quad$ Volumetric water content

$\rho_{\mathrm{d}} \quad$ Dry density

$\sigma_{3} \quad$ Minor principal stress

\section{Introduction}

The soil water retention curve (SWRC) describes the constitutive relationship between the water energy potential of the soil water and the amount of water stored in the soil. It reflects the hydraulic state of a soil as a result of 
solid-fluid interaction, which is dominated by capillary and/or adsorption mechanisms. These strongly affect the hydro-mechanical properties and stress-strain behaviour of unsaturated soils. In view of its major importance in the context of unsaturated soil mechanics, the soil water retention behaviour of natural soils in various forms (mostly after compaction or in reconstituted form) as expressed by their SWRC has been extensively investigated (e.g. [6, 15, 17, 25, 26, 32, 42, 45] amongst many others). It has thus been established that a number of factors affect the SWRC of a soil. These include soil structure, stress history and state, initial water content and void ratio of compacted soils, chemistry of the pore fluid, as well as the volume change in the soil through swelling, shrinkage, loading or unloading, which affect the water retention of the soil. Recent literature (e.g. [8, 23, 30, 47]) has focused in particular on the effect of fabric/structure evolution of compacted/aggregated clayey soils during generalised hydro-mechanical paths. As a result of this research, recent models describing the water retention of compacted soils (e.g. $[13,36])$ explicitly accounted for the evolving structure/fabric of the aggregated soil, distinguishing between two levels of structure of aggregated soils: intra-aggregate (micropores) and inter-aggregate (macropores) [1, 22].

Despite the extensive research on the SWRC, relatively little is known on the soil water retention behaviour of artificially cemented materials (e.g. with cement, lime and fly ash), commonly used for ground improvement applications in various engineering projects. Various reasons can be identified to anticipate that the behaviour of chemically treated soils could be different to that of the same soils before treatment. During the long duration of the SWRC tests, the chemically treated soils are expected to experience continuous changes due to chemical reactions which are summarised in the following section; these can affect the treated soil in terms of both mineralogy and structure (fabric and bonding); both these factors affect the SWRC of the soil [36]. In general, lime-treated soils are less deformable when subject to changes in moisture content than the corresponding untreated soils due to chemically induced cementation bonding (weak or strong) and/or possible mineralogy changes [27]. It is also possible that ageing or dissolution of the bonds can occur during cycles of drying and wetting, gradually modifying the structure of the soil [21]. This is believed to further promote hysteresis of water retention characteristics due to changes in soil pore structure; some leaching of the still unused lime upon reversal of the conditions can also occur, making less lime available for further reactions. These complex interactions are expected to lead to changes in soil water flow amongst pores and ultimately affect the water retention of the soil, further enhancing hysteresis, as manifested by the differ- ences between wetting and drying SWRC. It is therefore possible that the water retention and volume change behaviour of chemically treated soils upon drying and wetting presents some differences compared with the behaviour of untreated soils, which is of importance to investigate for engineering applications of chemical ground improvement.

The aim of this paper is to provide experimental evidence on the water retention behaviour of lime-treated high plasticity clays, by studying the effect of lime treatment on the water retention and the corresponding volume change upon wetting/drying of a high plasticity, high plasticity clay from the UK (London Clay). This will be based on SWRC data obtained from a number of tests carried out with a variety of techniques, namely testing using contact filter paper, and suction-controlled testing through axis translation using a pressure plate apparatus and a triaxial apparatus. The three techniques impose different boundary conditions, affecting stress state. It is, however, common practice in the geotechnical literature to combine different suction measurement/control techniques and apparatus to obtain the SWRC of soils (e.g. [12, 24, 28, 34, 35, 38, 40]). In the literature, for untreated unsaturated soils there is some ambiguity as to the effect of these different conditions on the SWRC (whose reported form is potentially affected by the measurement methodology). It was therefore considered of interest to use more than one techniques in this study (when possible) to investigate whether the results for the chemically treated soils are consistent regardless of the measurement technique, especially as different testing methods are usually valid within different suction ranges. In addition to investigating the possible effect of common influencing factors considered when assessing the SWRC of natural (untreated) soils (i.e. initial water content, compaction dry density, mean net stress), additional effects of particular relevance to chemically treated soils will be considered, namely the curing time and also curing method. The latter is distinguished into air (i.e. curing at constant water content) versus water curing, corresponding, respectively, to in situ curing where the soil would be covered by an impermeable membrane or cured by the application of water on the soil surface at frequent intervals.

\section{Background}

The effects of lime treatment on the physicochemical properties of fine-grained soils have been widely investigated. These can be attributed to a number of chemical reactions altering the soil nature and structure. The main two chemical reactions are: 
(a) an immediate ion exchange reaction between exchangeable clay ions and calcium ions provided by the lime. Cation exchange appears to be the first step towards more permanent changes; following a modification of the electrolyte content in the water due to the increased exchangeable calcium ion concentration, flocculation and agglomeration of the soil particles occur, transforming the plastic soil to a more granular and less plastic material [7]. As a result of this reaction, the soil generally acquires an aggregated, more porous and less deformable structure [14, 29]. In the context of SWRC studies, this would be expected to affect water retention especially in the zone where capillary phenomena predominate;

(b) long-term pozzolanic reactions depending on the availability of additional lime (beyond the amount used for immediate reactions); these are reactions between lime, silica and alumina, producing cementing agents. They are caused by the highly alkaline environment upon lime addition, which promotes dissolution of siliceous and aluminous compounds from the clay mineral lattice, reacting with calcium ions in the pore water to form calcium silicate hydrates, calcium aluminate hydrates and hydrated calcium aluminosilicates. The time-dependent pozzolanic product distribution and formation of gels in soil microstructures can potentially change soil pore connectivity as well as pore size distribution [9, 29].

Although it is clear that the above changes can potentially affect the water retention of the lime-treated soil, research on the soil water retention behaviour of limetreated materials is relatively limited. Examples of relevant studies include Russo [37] and Tedesco and Russo [41], who used the pressure plate apparatus to investigate the SWRC of a dynamically compacted quicklime-treated alluvial silty soil from Italy. The latter paper focused on the effect of curing time (7- vs. 28-day curing) on the SWRC and linked the SWRC changes to mercury intrusion porosimetry (MIP) studies. In addition, Khattab and AlTaie [20] studied the SWRC of three lime-stabilised expansive soils from Mosul City, Iraq, upon single drying paths in the suction range of $0-1000 \mathrm{kPa}$, using the osmotic method. All three papers recognised that the lime-treated soil compacted dry of optimum had a reduced water retention (compared with soils compacted wet of optimum) due to the larger voids developed. However, an overall increase in the water retention of the lime-treated soil was noted in these papers. This contradicts findings showing that lime treatment results in increase in permeability due to the amount of large macropores forming (e.g. [3, 31]). On the other hand, the MIP study of the soil compacted at optimum water content in Tedesco and Russo [41] showed that shortly after the addition of lime (modification stage) relatively large diameter pores had formed $(4-40 \mu \mathrm{m})$, but in time the frequency of micropores $(0.01-0.2 \mu \mathrm{m})$ systematically increased. These observations were consistent with the reduction in the air-entry value of the treated soil as well as the observed increase in the water retention of the soil in time, for suction values greater than $100 \mathrm{kPa}$; this long-term effect was attributed to the development of cementation bonds between aggregates. It should be noted that the soil studied was treated with a lime percentage high enough to induce long-term pozzolanic reactions in addition to any early-stage modification reactions, which can explain the continued pronounced effect of the lime on the structure of the soil. Mavroulidou et al. [27] focused on the water retention, compressibility and overall volumetric behaviour of hydrated lime-treated London Clay, cured at a lime percentage only slightly higher than the initial lime consumption (ICL) of the soil. The drying SWRC of the statically compacted treated and untreated soils was determined using contact filter paper for a specific compaction void ratio and water content. The effect of freeswelling versus confined saturation conditions on the SWRC of the treated soil was also considered. These conditions, which would be of practical relevance for shallow and deep in situ lime mixing, respectively, were shown to affect the SWRC of untreated soils [11, 13]. The former saturation conditions resulted in a clear doubleporosity structure of the lime-treated soil which, based on the SWRC information, would be likely to be partially saturated in situ depending on the environmental conditions (unlike the natural London Clay which would be likely to remain saturated over a wider range of suctions). Finally, volume changes measured during filter paper testing as well as separate shrinkage tests showed that the lime considerably improved the volumetric stability of the soil upon drying. All these studies focused in particular on the drying SWRC and did not attempt to investigate the potential hysteresis of the SWRC of these materials upon cycles of drying and wetting despite their relevance for in situ conditions. Conversely, in a recent conference paper, Cuisinier et al. [12] assessed the SWRC of a quicklime-treated statically compared expansive clayey soil from the East of France over a wetting and drying path. In this investigation, the soil was treated with two different percentages of lime, one close to the ICL and a higher percentage, considered high enough to induce pozzolanic reactions. To achieve a wide range of suctions, suction measurements were performed with the osmotic technique and the salt solution technique. The SWRC of the treated soil was interpreted in the light of changes in the soil microstructure due to the effect of lime, based on MIP studies. This also led to a discussion on the link between fabric modification and observed volumetric strains. The 
drying SWRC of the lime-treated soil, cured at constant moisture conditions (referred to herein as 'air curing'- - see Sects. 3 and 4), was shown to have changed compared with that of the untreated soil, only in the region of suctions higher than about $20 \mathrm{MPa}$. This is unlike the findings in Russo [37]. It was also found that the SWRC was not affected by curing time (between 28 and 180 days); therefore, the effect of the lime treatment was attributed primarily to immediate reactions and compaction processes rather long-term reactions. MIP showed that lime addition resulted in an increase in micropores (which was more pronounced for the higher lime content) but had a rather limited effect on the macroporosity (unlike Tedesco and Russo [41]). Overall the void ratio of the lime-treated soil increased with lime content. It is also interesting to note that unlike Mavroulidou et al. [27], Cuisinier et al. [12] did not observe a considerable improvement in the shrinkage behaviour of the lime-treated soil, even for the highest quicklime percentage used (5\%). However, they noticed an improvement in the swelling behaviour upon wetting, accompanied by a reorganisation of the soil fabric.

From the above review, it can be seen that some gaps in the knowledge of the SWRC of lime-treated soils remain and further research is needed. This paper will provide further experimental evidence in this direction.

\section{Materials, equipment and experimental procedures}

\subsection{Materials and specimen preparation}

The London Clay soil used in this study was taken from a deep excavation from Westminster Bridge in London. Its basic characteristics are summarised in Table 1. The soil was air-dried for a month at room temperature; it was then pulverised with a rubber pestle and subsequently ground using a mechanical grinder; the portion passing the $425-\mu \mathrm{m}$ BS sieve was retained for the testing. The particle size distribution of the retained soil is shown in Fig. 1.

For the chemical treatment of this soil, commercially available hydrated lime was used. The relative proportion of calcium hydroxide to calcium oxide was found to be 4.88:1.00 based on chemical analysis on the lime sample carried out in duplicate. Based on plasticity tests and initial consumption of lime (ICL) tests [16], the minimum necessary percentage of lime to treat this soil was determined to be approximately $4 \%$ (based on the dry soil mass); this percentage was used throughout the tests presented in this paper. After mixing thoroughly the dry powders of the soil and lime, water was carefully added at small increments, and the wet paste was mixed thoroughly. It was then stored in two layers of sealable plastic bags and carefully
Table 1 Properties of London Clay soil used in this study

\begin{tabular}{ll}
\hline Clay content \% of which & 51 \\
Illite $(\%)$ & 50 \\
Smectite (\%) & 26 \\
Kaolinite (\%) & 15 \\
Chlorite (\%) & 9 \\
Sand & $4 \%$ \\
Silt & $45 \%$ \\
Liquid limit (\%) & 64 \\
Plastic limit (\%) & 26 \\
Plasticity index $(\%)$ & 38 \\
Activity Index & 0.75 (normal activity) \\
Specific gravity $\left(G_{\mathrm{s}}\right)$ & 2.75 \\
pH & 7.2 \\
Soluble sulphate content & $<0.1 \%$ \\
Total sulphate content & $<0.1 \%$ \\
\hline
\end{tabular}

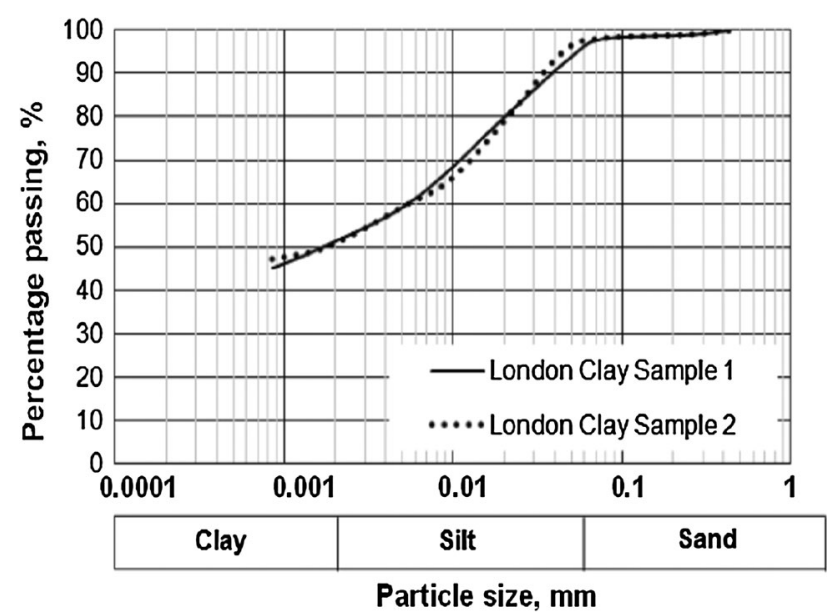

Fig. 1 Particle size distribution of the London Clay

preserved in a high-humidity chamber for a mellowing period of $24 \mathrm{~h}$. For meaningful comparisons, it was important to accurately control the initial specimen properties. For this reason, static compaction was selected as the best way of exerting sufficient control over the compaction process of a clayey soil [18]. For the filter paper and pressure plate tests, statically compacted standard oedometer size specimens (i.e. cylinders of $75 \mathrm{~mm}$ diameter and $20 \mathrm{~mm}$ height) were prepared directly in oedometer cutting rings used as moulds. To investigate the influence of the mean net stress on the SWRC, two statically compacted triaxial testing size specimens (of $50 \mathrm{~mm}$ diameter and $100 \mathrm{~mm}$ height) were also prepared in split moulds of the appropriate dimensions. The soil was placed in the moulds in two or ten equal layers (for the oedometer and triaxial size specimens, respectively) and compressed at a monotonic displacement rate of $1 \mathrm{~mm} / \mathrm{min}$ until the 
Table 2 Standard proctor compaction characteristics of the untreated and lime-treated soils

\begin{tabular}{lll}
\hline Soil & $w_{\text {opt }}$ & $\rho_{\mathrm{dmax}}\left(\mathrm{g} / \mathrm{cm}^{3}\right)$ \\
\hline London Clay & 26 & 1.43 \\
$4 \%$ Lime-treated London Clay & 30 & 1.26 \\
\hline
\end{tabular}

required height (corresponding to the set target dry density) was reached. The loading ram was then held in contact with the soil for another 5 min to reduce the rebound upon unloading [18]. Regarding the static compaction characteristics used in this study (see Tables 4, 5, 6, 7, 8), it was observed that the two soils (treated vs. untreated) had different dynamic (standard Proctor compaction) characteristics due to the effect of lime treatment (see Table 2). A point of reference was therefore needed for the investigations in order to compare the SWRC of the treated and that of the untreated soil [48]. This was chosen to be the target dry density of the untreated soil, which was used as the 'control' dry density for the parametric study shown in this paper. The effect of the compaction dry density was, however, studied in the first set of investigations (see Fig. 4a-f). Water content for both types of specimen was kept to the dry side of the respective Proctor optimum for all comparisons to ensure that the resulting structure after compaction was qualitatively similar for the two soils. The only exception to this is the second set of comparisons investigating the effect of the compaction water content (Fig. 5a-f), but there the effect of water contents dry and wet of optimum of the treated and untreated soils, respectively, is consistently compared. Note that it has been argued that static compaction (which has been adopted here) as opposed to dynamic compaction induces anyway aggregation of the soil particles even for compaction on the wet side [2].

The lime-treated specimens were then left to cure for the required curing period. In this paper, indicative results from two different methods of curing are presented, namely water curing and air curing. When using the latter curing method, the specimens were extracted from the cutting rings, wrapped in several layers of cling film and stored in controlled environmental conditions for the specified curing period (constant moisture content curing). When using the water-curing method, curing was performed in parallel with water saturation. A constant volume saturation method was used to control the initial void ratios of the specimens prior to SWRC testing, although some small changes in the initial void ratios still occurred due to some slight expansion after extruding the specimens from the moulds at the end of the saturation process. During this saturation/curing method, the specimens (1 day after compaction and still in the cutting ring) were sandwiched between two coarse porous discs and secured inside a saturation frame (holding three oedometer size samples at a time); they were then submerged in distilled, de-aired water. The saturation frame was constrained from the upper and lower ends to prevent soil from swelling upon wetting (see Fig. 2). Note that when using the constant volume wetting method, it was difficult to reach high degrees of

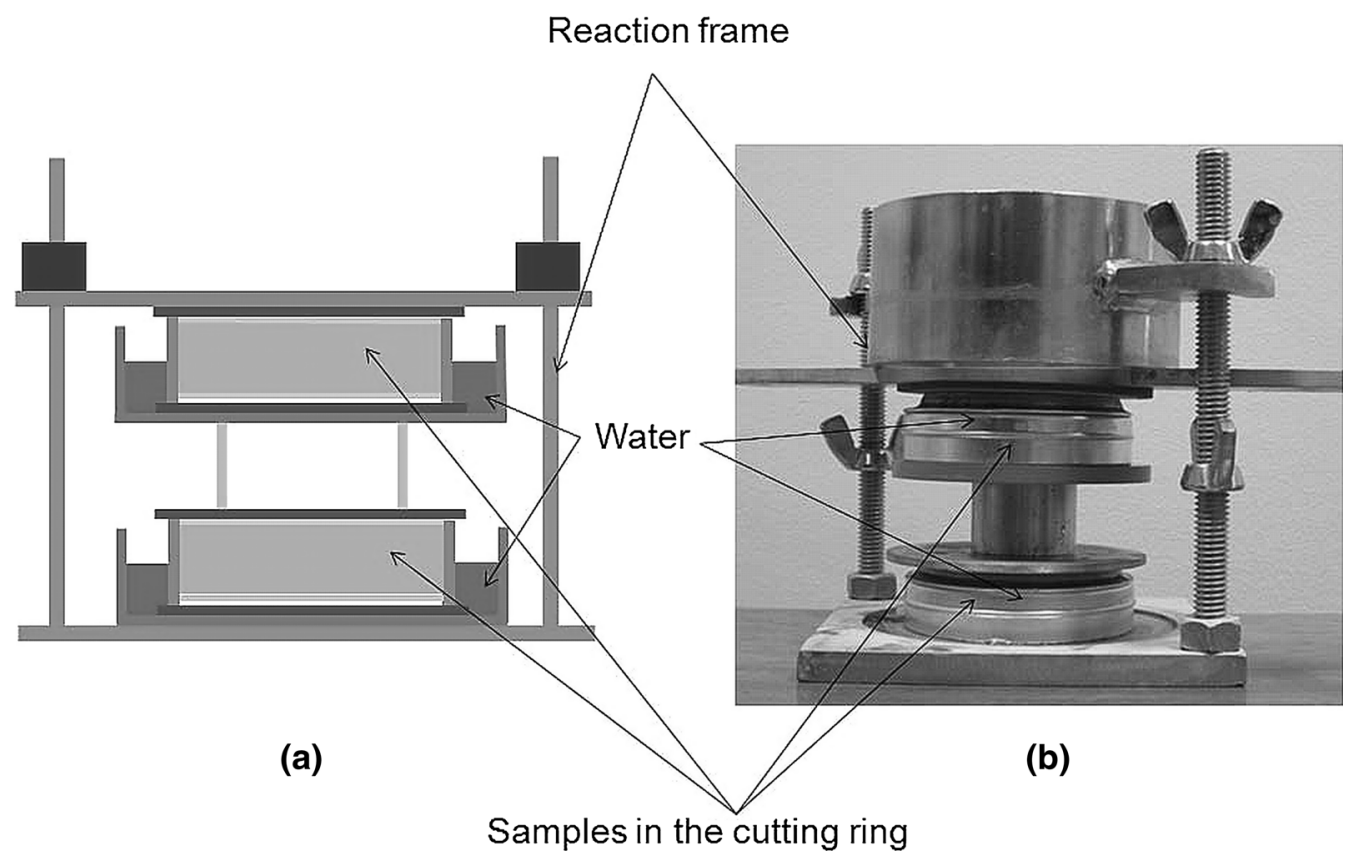

Fig. 2 Saturation frame used in this study 
Table 3 Calibration relationships for the filter paper suction measurement

\begin{tabular}{llll}
\hline & Filter paper water content, $w_{f}, \%$ & Matric suction, $s, \mathrm{kPa}$ & References \\
\hline Initially dry paper & $w_{f} \leq 47$ & $s=10^{\left(4.842-0.0622 w_{f}\right)}$ & Chandler and Gutierrez [41] \\
& $w_{f}>47$ & $s=10^{\left(6.05-2.48 \log _{10} w_{f}\right)}$ & \\
Initially wet paper & $w_{f} \leq 15.47$ & $s=10^{\left(4.842-0.0622 w_{f}\right)}$ & Dineen [32] \\
& $15.47<w_{f} \leq 57.2$ & $s=10^{\left(4.573-0.0449 w_{f}\right)}$ & \\
& $w_{f}>57.2$ & $s=10^{\left(2.904-0.0158 w_{f}\right)}$ & \\
\hline
\end{tabular}

saturation due to the confinement of the specimen. To improve specimen saturation, the specimens (held in the confining frame) were placed in a sealed bigger cell and connected to a suction pump for $15 \mathrm{~min}$; this was followed by back-pressure saturation during which the specimen was slowly filled with water entering from the lower side of the cell. This saturation process lasted for 7 days and enabled degrees of saturation of $95-99 \%$ to be reached. The $\mathrm{pH}$ of the water during saturation/water curing was regularly monitored using $\mathrm{pH}$ paper to ensure that this saturation procedure did not lead to the removal of calcium ions (necessary for chemical reactions) from the pore water. No change in the colour of the paper was noted during the saturation/curing period.

A final point that had to be considered in the testing plan was whether the soil would potentially keep curing between measurement points, which could have an effect on the resulting SWRC. To address this, the evolution of reactions with time was assessed based on preliminary unconsolidated undrained (UU) triaxial tests presented in Zhang et al. [48] for six different curing periods between 1 and 166 days (the latter period covers the typical duration of most tests presented here). These tests showed that for this amount of lime (4\%), i.e. just above the ICL of the soil, curing beyond 7 days did not result in any further improvement in the shear strength of the soil (in fact for 166 days there was a slight drop in strength).

\subsection{SWRC testing techniques and apparatus}

\subsubsection{Filter paper testing}

The filter paper procedure used in the present research was based on ASTM D-5298 [4] with the following two main differences based on procedures developed at Imperial College, London, and presented in a number of doctoral theses (e.g. [15, 18, 28]): (1) one single soil specimen of oedometer size was used, sandwiched between two Perspex discs; three filter papers were used on each side of the specimen between the soil and the Perspex discs (ASTM D-5298 uses two equal pieces soil between which three filter papers are sandwiched); (2) the calibration formulae according to Chandler and Gutierrez [10] and Dineen [15] were used for initially dry and wet filter paper, respectively, as given in Table 3 .

To obtain the drying curves, the soil specimen was left to air-dry slowly to the desired water content for each measurement point, until its residual water content was reached. One single soil specimen (and not multiple 'identical' specimens at different initial water contents) was used to determine each SWRC. For the wetting curves, three wet filter papers held by tweezers were placed on either side of the specimen. The papers were soaked in distilled water until a mass of $2 \mathrm{~g}$ of water in total was absorbed by the papers. This amount of water on each side of the specimen was found to be appropriate to alleviate measurement errors due to evaporation or excessively small changes in suction [28].

\subsubsection{Suction-controlled triaxial apparatus}

To consider the influence of stress state on the SWRC, two air-cured specimens were tested in a suction-controlled triaxial stress path system using the axis translation technique. The triaxial system consisted of one 1000 cc GDS Instruments advanced pressure and volume controller for cell pressure control, one $200 \mathrm{cc}$ GDS Instruments advanced pressure and volume controller for pore water pressure, one air regulator to control the pore air pressure and a triaxial cell with a pedestal incorporating a $1500 \mathrm{kPa}$ high air-entry value (HAEV) disc. After 1 week of air curing, the specimens were placed in the triaxial cell; the suction was then translated to $500 \mathrm{kPa}$ (i.e. a suction lower than the initial as-compacted suction (i.e. typically $550-650 \mathrm{kPa}$ for the lime-treated soil, depending on the compaction conditions) and left to equalise before the SWRC testing. To apply the required mean net stress ( $p$ $u_{\mathrm{a}}$ ), this was increased or decreased by changing the cell pressure $\sigma_{3}$ at a slow rate of $0.6 \mathrm{kPa} / \mathrm{h}$ ensuring that no excess pore water pressure developed and that, consequently, suction remained constant during testing. After completion of consolidation under the target mean net 
stresses (of 100 and $200 \mathrm{kPa}$, respectively, for the two specimens), the wetting and drying SWRC testing was performed under a constant mean net stress. During wetting and drying, suction was controlled by increasing or decreasing the pore water pressure, respectively, while maintaining the same air pressure. To obtain each measurement point in the triaxial apparatus, 7 days were typically needed (this included the slow rate of incremental suction changes of $1 \mathrm{kP} / \mathrm{h}$, i.e. 4 days to reach each new suction level, plus a subsequent period of 2-3 days for excess pore pressures to dissipate). To carry out one complete wetting and drying SWRC test (for a suction cycle of 500-0-550 kPa), a 110-day period was necessary. During the wetting and drying, local linear variable differential transformers (LVDTs) were used for the volume measurements.

\subsubsection{Modified pressure plate apparatus}

The pressure plate apparatus system designed for this study, consisted of a rigid wall permeameter cell with a modified pedestal, incorporating a high air-entry value (HAEV) disc for the application of axis translation suction control technique. To prevent air leakage often observed in conventional pressure plate devices [25, 46], the base pedestal plate was modified so that the HAEV disc was integrated in the base pedestal plate of the apparatus. The system was completed with a burette and a flushing device (see Fig. 3). All pipes and the HAEV disc were de-aired using a hydraulic pump to apply a low positive water pressure of a max $50 \mathrm{kPa}$ under the disc, until water appeared on the top surface of the disc. During testing, a small glass tray filled with distilled water was placed in the pressure plate cell to maintain constant humidity

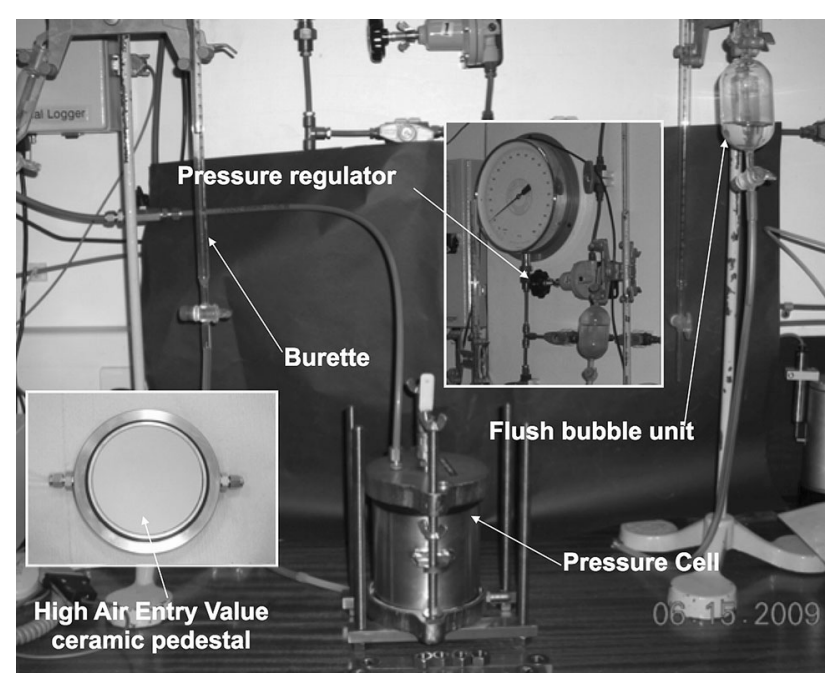

Fig. 3 Pressure plate apparatus used in this study throughout the test. The required suction level was applied by increasing or decreasing the air pressure stepwise, until the drying or wetting branch of the SWRC, respectively, was obtained. The observed period for suction equilibration in the pressure plate apparatus was 3-7 days for each suction level. For consistency in the measurements and to maintain the same equilibration period as in the triaxial apparatus method, a fixed period of 7 days was adopted for suction equilibration, even in the lower suction stage where the necessary time for suction equilibrium was shorter. After suction equilibration for each suction level, the specimen was taken out of the cell and mass and volume measurements (using digital callipers) were performed.

\section{Presentation of results}

The presentation of the results in this section investigates how different factors affect the form of the SWRC of the studied soils one at a time. Therefore, some of the results are plotted in more than one figure to investigate the effect of one factor at a time. Similarly, for better clarity, separate tables with specimen information, initial conditions and details of the testing paths used are presented together with each set of figures shown.

For the sake of brevity, in the following discussion the notation $w-s, S_{\mathrm{r}}-s, S_{\mathrm{r}}-w, e-s, \varepsilon_{\mathrm{v}}-s$ and $e-w$ will refer, respectively, to the relationships between (a) gravimetric water content and matric suction, (b) degree of saturation and matric suction, (c) degree of saturation and gravimetric water content, (d) void ratio and matric suction, (e) volumetric strain and matric suction and (f) void ratio versus gravimetric water contents of each presented soil.

The observations that can be made based on the results are presented in the following sections.

\subsection{Effect of initial (compaction) dry density}

Figure 4a-f represents indicative drying filter paper data for water-cured specimens, compacted dry of the Proctor optimum and subsequently subjected to saturation prior to filter paper testing; on the same plots untreated soil results compacted dry of optimum are also shown (for the latter specimens drying started from the as-compacted conditions without prior wetting/saturation). The specimen characteristics (as-compacted state), the testing method and hydraulic paths followed are given in Table 4 .

From the figures, it can be seen that the curves showing void ratio changes with suction $e-s$ (Fig. 4c) or the shrinkage curves (i.e. $e-w$ curves in Fig. $4 \mathrm{e}$ ) are similar in shape and their relative position is only affected by the initial dry density, so that specimens with the lower dry densities plot higher than curves of the same soil 

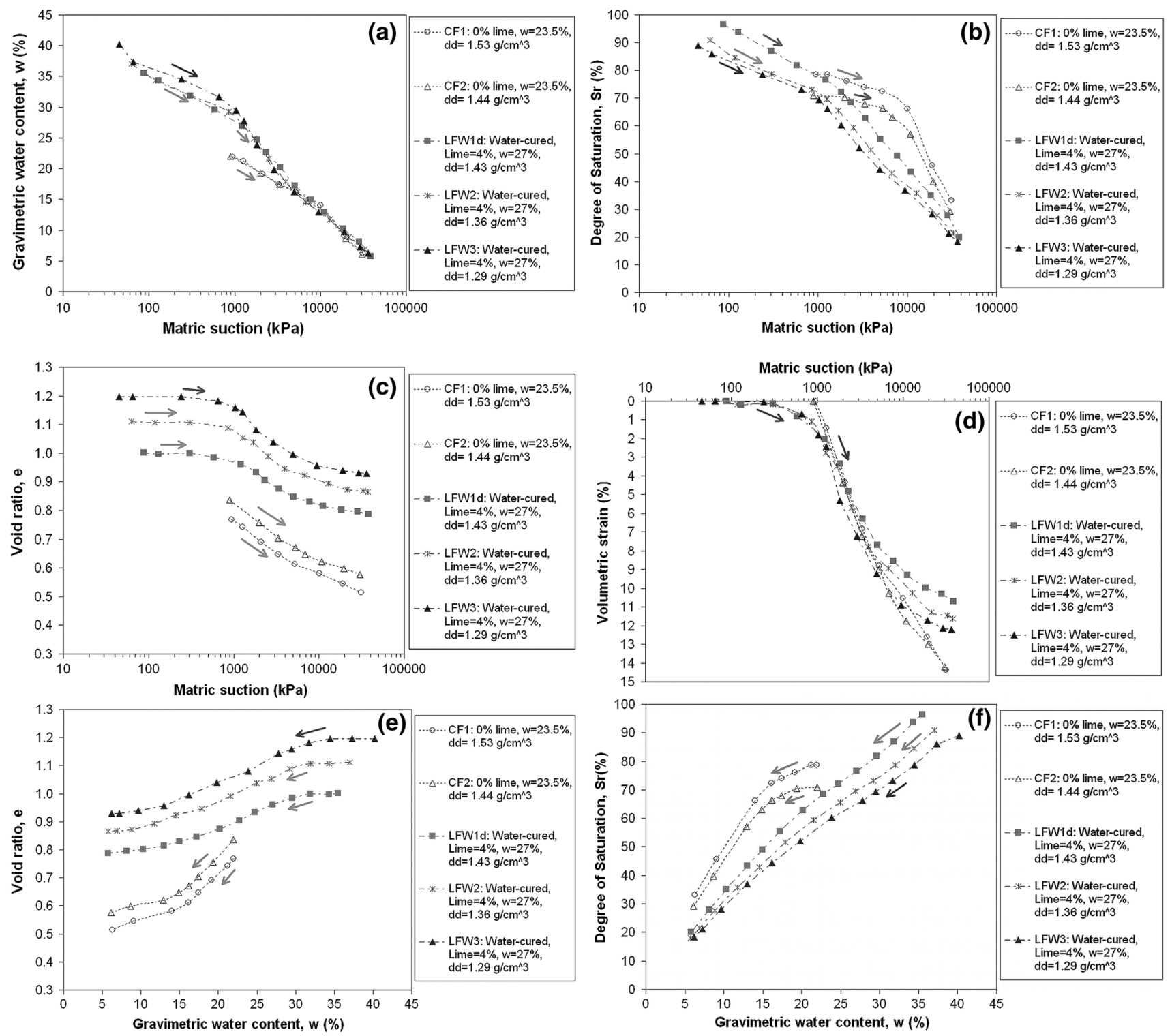

Fig. 4 Effect of compaction dry density; a gravimetric water content versus matric suction relationship; $\mathbf{b}$ degree of saturation versus matric suction relationship; c void ratio versus matric suction relationship; d volumetric strain with matric suction change; e void ratio versus gravimetric water content relationship; f degree of saturation versus gravimetric water content relationship

compacted at higher dry density. This is reflected in the $S_{\mathrm{r}}-$ $s$ and $S_{\mathrm{r}}-w$ curves (Fig. $4 \mathrm{~b}, \mathrm{f}$ ) which are similar in shape but specimens with higher initial dry densities are located higher than the respective curves of specimens with lower initial dry densities. Consistently with the literature for untreated compacted soils which shows that the air-entry value depends on the compaction dry density (e.g. [35]), the suctions corresponding to the points of maximum curvature of the $S_{\mathrm{r}}-S$ curves of the treated soil decrease with decreasing compaction densities (see Fig. 4b). However, the rates of desaturation of each soil (lime-treated soil and untreated soil, respectively) do not appear to be affected by its respective original dry density: the slopes of the three lime-treated soil curves beyond the point of maximum curvature (and hence the rates of desorption) are similar, irrespective of the compaction dry density. The same can be noted for the two SWRCs of the untreated soil. The above observations regarding the similarity of the $S_{\mathrm{r}}$ $s$ curves have been typically reported in the literature for untreated soils of different types (e.g. [33]). Conversely, the $w-s$ curves (Fig. 4a) show some small differences at lower suctions, but subsequently after their maximum curvature point at about $1000 \mathrm{kPa}$ the $w-s$ curves practically coincide (as reported in the literature for untreated soils, where the $w-s$ curves are shown to converge at higher suctions, irrespective of compaction dry densities, whereas 
Table 4 As-compacted specimen characteristics and testing paths (effect of compaction dry density)

\begin{tabular}{|c|c|c|c|c|c|c|c|c|c|}
\hline $\begin{array}{l}\text { Specimen } \\
\text { ID }\end{array}$ & $\begin{array}{l}\text { Dry density } \\
\left(\mathrm{g} / \mathrm{cm}^{3}\right)\end{array}$ & $\begin{array}{l}\text { Water } \\
\text { content } w \%\end{array}$ & $\begin{array}{l}\text { Degree of } \\
\text { saturation } S_{\mathrm{r}} \%\end{array}$ & $\begin{array}{l}\text { Suction s } \\
(\mathrm{kPa})\end{array}$ & $\begin{array}{l}\text { Lime } \\
\%\end{array}$ & $\begin{array}{l}\text { Test } \\
\text { method }\end{array}$ & $\begin{array}{l}\text { Curing } \\
\text { method }\end{array}$ & $\begin{array}{l}\text { Path followed after } \\
\text { compaction }\end{array}$ & Figure number \\
\hline $\mathrm{CF} 1$ & 1.526 & 23.46 & 80.44 & 700 & 0 & $\begin{array}{l}\text { Filter } \\
\text { paper }\end{array}$ & N/A & $\begin{array}{l}\text { Drying to residual } \\
\text { water content }\end{array}$ & Figure $4 \mathrm{a}-\mathrm{f}$ \\
\hline $\mathrm{CF} 2$ & 1.440 & 23.48 & 71.02 & 660 & 0 & $\begin{array}{l}\text { Filter } \\
\text { paper }\end{array}$ & N/A & $\begin{array}{l}\text { Drying to residual } \\
\text { water content }\end{array}$ & Figure $4 \mathrm{a}-\mathrm{f}$ \\
\hline LFW1d & 1.430 & 27.00 & 81.3 & 600 & 4 & $\begin{array}{l}\text { Filter } \\
\text { paper }\end{array}$ & $\begin{array}{l}\text { Water: } \\
1 \text { week }\end{array}$ & $\begin{array}{l}\text { 1) Saturation } \\
\text { 2) Air drying } \\
\text { 3) Wetting }\end{array}$ & Figure $4 \mathrm{a}-\mathrm{f}$ \\
\hline LFW2 & 1.359 & 27.00 & 73.19 & 540 & 4 & $\begin{array}{l}\text { Filter } \\
\text { paper }\end{array}$ & $\begin{array}{l}\text { Water: } \\
1 \text { week }\end{array}$ & $\begin{array}{l}\text { 1) Saturation } \\
\text { 2) Drying }\end{array}$ & Figure $4 \mathrm{a}-\mathrm{f}$ \\
\hline LFW3 & 1.292 & 27.00 & 66.31 & 500 & 4 & $\begin{array}{l}\text { Filter } \\
\text { paper }\end{array}$ & $\begin{array}{l}\text { Water: } \\
1 \text { week }\end{array}$ & $\begin{array}{l}\text { 1) Saturation } \\
\text { 2) Drying }\end{array}$ & Figure $4 \mathrm{a}-\mathrm{f}$ \\
\hline
\end{tabular}

differences due to compaction densities occur at low suction ranges) (see e.g. $[5,35]$ ).

Lime-treated specimens had lower volumetric strains than untreated ones for all initial dry densities (Fig. 4d), especially for higher compaction densities. The untreated specimen with the higher dry density initially is less deformable, but eventually at very high suctions the volumetric strain curves of the untreated soil appear to practically converge. It is interesting to note that for the limetreated specimens which were cured in water and hence started drying from a higher degree of saturation (untreated specimens started drying from compaction conditions), there is no shrinkage initially until suctions consistent with the point of maximum curvature of the respective $S_{\mathrm{r}}-$ $s$ curves (see Fig. $4 \mathrm{~b}$ ). The $S_{\mathrm{r}}-s$ curves show a continuous decrease in the degree of saturation although the void ratio remains practically unchanged within this suction range. On the other hand, the $w-s$ curve shows a continuous decrease in gravimetric water content within this suction range. This implies that the change in the degree of saturation within this suction range is mostly due to gravity drainage from the macropores of the soil, which are larger than those of the untreated soil (see later SEM analysis, Fig. 13) (a double-porosity behaviour, characteristic of specimens compacted dry of optimum is clear in these curves manifested by the two different slopes in the curves before and after suctions corresponding to the respective points of maximum curvature of the $S_{\mathrm{r}}-s$ curves). This is reflected by the higher suctions of approximately $5000 \mathrm{kPa}$, corresponding to the maximum curvature points of the curves of the untreated specimens (see Fig. 4b). In addition to its initial smaller macrovoids, the untreated soil experiences continuous shrinkage throughout the suction ranges (see Fig. 4c, e). Thus, the untreated soil maintains higher degrees of saturation throughout the range of measured suctions or water contents; the $S_{\mathrm{r}}-s$ curves show an almost constant degree of saturation up and to the point of maximum curvature, unlike those of the treated soil (Fig. 4b). This reflects again the effect of shrinkage as the corresponding $S_{\mathrm{r}}-w$ curves in Fig. $4 \mathrm{f}$ do show a continuous decrease in the $S_{\mathrm{r}}$ with $w$-although slower until the point of maximum curvature).

Higher suctions beyond the maximum curvature point appear to trigger some shrinkage of the lime-treated specimens 4(c) and (e). The lime-treated soil curves appear to tend to level out at suctions above approximately $20,000 \mathrm{kPa}$ (and water contents below $10 \%$ ); it is not obvious that the same happens for the untreated soil. Overall, although lime treatment did not eliminate shrinkage (as also observed in [12]), the overall shrinkage/void ratio change in the treated soil was lower compared with the untreated specimen, suggesting an improvement in the volumetric response of the treated soil.

\subsection{Effect of initial (compaction) water content}

The results shown in Fig. 5a-f are based on drying filter paper tests of specimens starting from as-compacted conditions. For the lime-treated specimens, testing started 2 weeks after air curing. Note that the curves do not record the original (compaction) water contents (hence the starting water contents of the curves are not the same as the respective compaction water contents). The as-compacted specimen characteristics are, however, recorded in Table 5 together with the testing paths followed.

The results show some clear differences in the SWRC of specimens with different initial (compaction) water contents when plotted in the form of $S_{\mathrm{r}}-s$ (mostly) but also (to a lesser extent) in the form of $w-s$ curves (Fig. 5b, a, respectively). However, all $S_{\mathrm{r}}-s$ and $w-s$ curves essentially converge at higher suctions (with a certain scatter in the data) regardless of the previous differences, showing that 

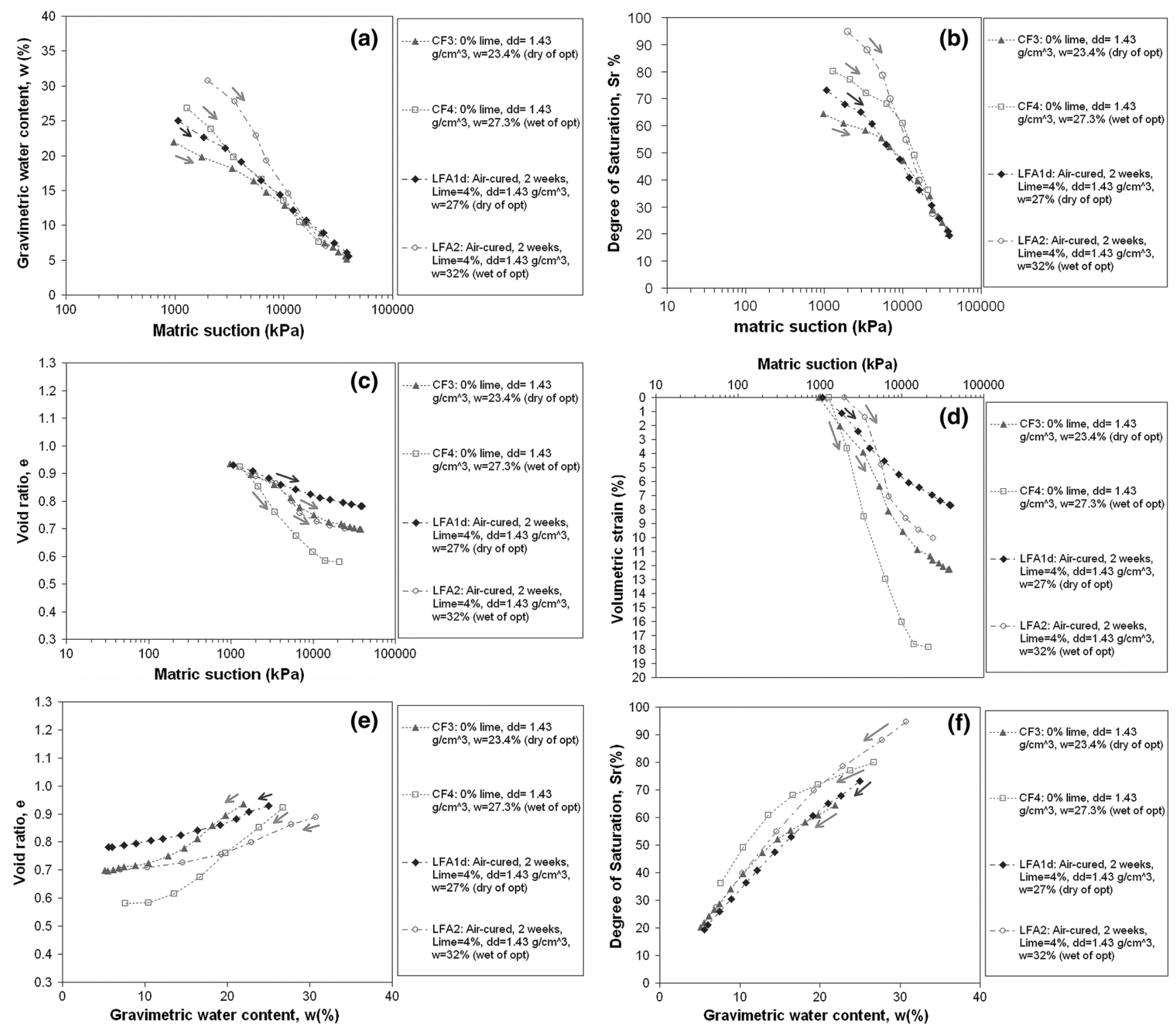

Fig. 5 Effect of compaction water content; a gravimetric water content versus matric suction relationship; b degree of saturation versus matric suction relationship; c void ratio versus matric suction relationship; d volumetric strain with matric suction change; e void ratio versus gravimetric water content relationship; f degree of saturation versus gravimetric water content relationship

Table 5 As-compacted specimen characteristics and testing paths (effect of compaction water content)

\begin{tabular}{|c|c|c|c|c|c|c|c|c|c|}
\hline $\begin{array}{l}\text { Specimen } \\
\text { ID }\end{array}$ & $\begin{array}{l}\text { Dry density } \\
\left(\mathrm{g} / \mathrm{cm}^{3}\right)\end{array}$ & $\begin{array}{l}\text { Water } \\
\text { content } w \%\end{array}$ & $\begin{array}{l}\text { Degree of } \\
\text { saturation } S_{\mathrm{r}} \%\end{array}$ & $\begin{array}{l}\text { Suction s } \\
(\mathrm{kPa})\end{array}$ & $\begin{array}{l}\text { Lime } \\
\%\end{array}$ & $\begin{array}{l}\text { Test } \\
\text { method }\end{array}$ & $\begin{array}{l}\text { Curing } \\
\text { method }\end{array}$ & $\begin{array}{l}\text { Path followed after } \\
\text { compaction }\end{array}$ & Figure number \\
\hline $\mathrm{CF} 3$ & 1.43 & 23.4 & 69.92 & 690 & 0 & $\begin{array}{l}\text { Filter } \\
\text { paper }\end{array}$ & N/A & $\begin{array}{l}\text { Drying to residual } \\
\text { water content }\end{array}$ & Figure $5 \mathrm{a}-\mathrm{f}$ \\
\hline $\mathrm{CF} 4$ & 1.43 & 27.25 & 75.45 & $\mathrm{a}$ & 0 & $\begin{array}{l}\text { Filter } \\
\text { paper }\end{array}$ & N/A & $\begin{array}{l}\text { Drying to residual } \\
\text { water content }\end{array}$ & Figure $5 \mathrm{a}-\mathrm{f}$ \\
\hline LFA1d & 1.43 & 27.00 & 81.2 & 600 & 4 & $\begin{array}{l}\text { Filter } \\
\text { paper }\end{array}$ & $\begin{array}{l}\text { Air: } \\
2 \text { weeks }\end{array}$ & Start drying & Figure $5 \mathrm{a}-\mathrm{f}$ \\
\hline LFA2 & 1.431 & 32.00 & 96.2 & $\mathrm{a}$ & 4 & $\begin{array}{l}\text { Filter } \\
\text { paper }\end{array}$ & $\begin{array}{l}\text { Air: } \\
2 \text { weeks }\end{array}$ & $\begin{array}{l}\text { Drying to residual } \\
\text { water content }\end{array}$ & Figure $5 \mathrm{a}-\mathrm{f}$ \\
\hline
\end{tabular}

${ }^{a}$ Missing measurement 

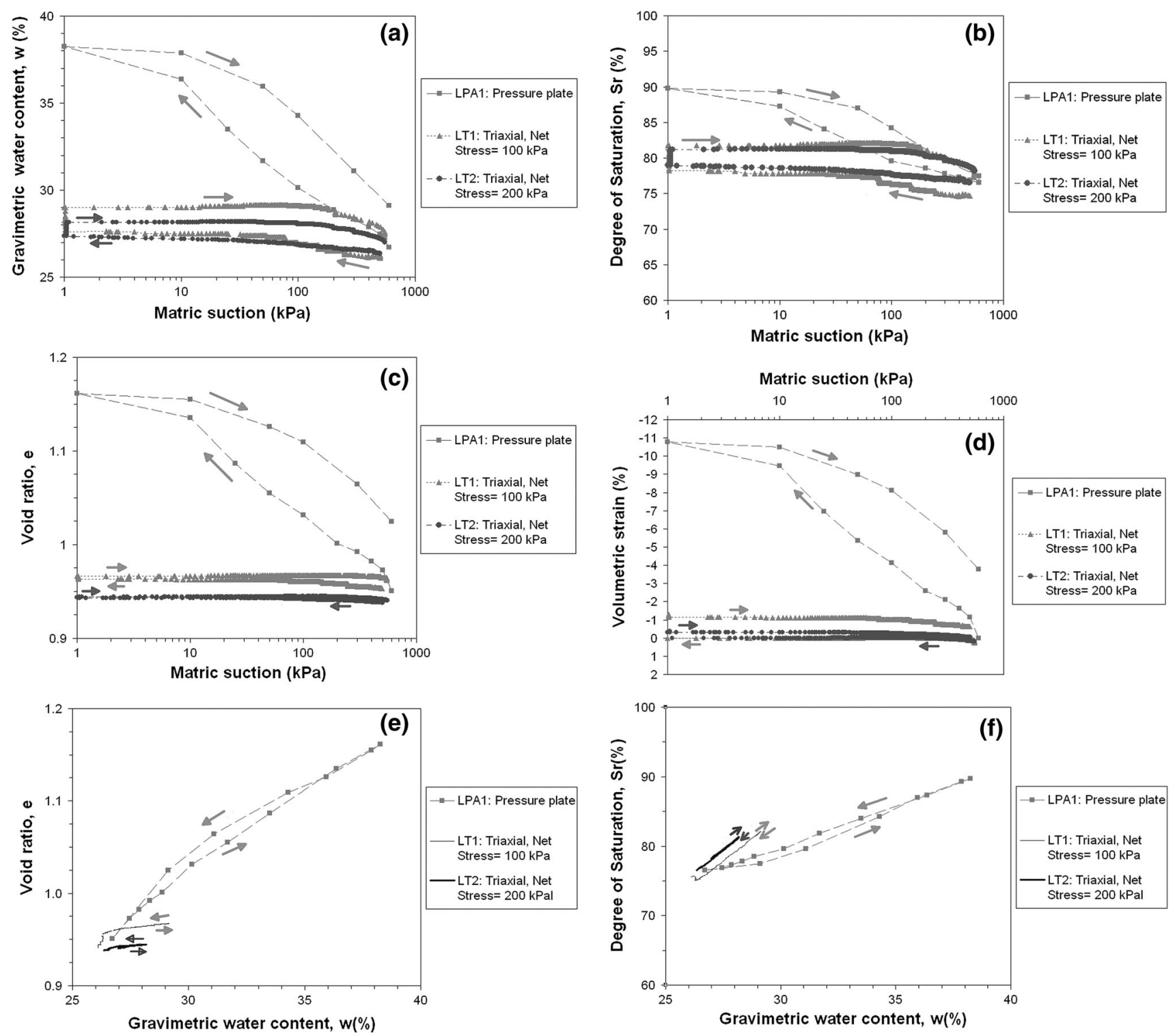

Fig. 6 Effect of net stress; a gravimetric water content versus matric suction relationship; $\mathbf{b}$ degree of saturation versus matric suction relationship; c void ratio versus matric suction relationship; $\mathbf{d}$ volumetric strain with matric suction change; e void ratio versus gravimetric water content relationship; $\mathbf{f}$ degree of saturation versus gravimetric water content relationship

the micropores of the lime-treated soil are relatively insensitive to the initial differences in the compaction water content, as are those of the untreated soil. This observation has been frequently made in the literature on the SWRC of untreated soils (e.g. [35, 38]); here this proves to be true for the lime-treated soil as well, although for this type of soil it would have been possible that water content could have had an effect on chemical reactions; in turn the products of these could have affected the porosity of the soil at all scales.

The $e-s$ curves (Fig. 5c), the shrinkage curves $e_{-}$ $w$ (Fig. 5e), as well as the plots of volumetric strains versus suction (Fig. 5d), all point again at the fact that shrinkage is clearly lower for the lime-treated specimens compared with the untreated ones. The similarity of the shapes of the shrinkage curves $e-w$ for the same soil regardless of the compaction moisture content can also be noted. However, similarly to the untreated soil the lime-treated specimen compacted wet of the Proctor optimum is more deformable (see the higher shrinkage volumetric strains) than that compacted dry of the Proctor optimum. This is consequently reflected in the $S_{\mathrm{r}}-s$ and $S_{\mathrm{r}}-w$ curves (Fig. 5b, f, respectively) which show higher degrees of saturation for the soils compacted wet of the Proctor optimum than specimens compacted dry of optimum (for both limetreated and untreated specimens); this is due to the lower 
Table 6 As-compacted specimen characteristics, test method and paths (effect of mean net stress)

\begin{tabular}{|c|c|c|c|c|c|c|c|c|c|}
\hline $\begin{array}{l}\text { Specimen } \\
\text { ID }\end{array}$ & $\begin{array}{l}\text { Dry density } \\
\left(\mathrm{g} / \mathrm{cm}^{3}\right)\end{array}$ & $\begin{array}{l}\text { Water } \\
\text { content } w \%\end{array}$ & $\begin{array}{l}\text { Degree of } \\
\text { saturation } S_{\mathrm{r}} \%\end{array}$ & $\begin{array}{l}\text { Suction } \\
\mathrm{s}(\mathrm{kPa})\end{array}$ & $\begin{array}{l}\text { Lime } \\
\%\end{array}$ & $\begin{array}{l}\text { Test } \\
\text { method }\end{array}$ & $\begin{array}{l}\text { Curing } \\
\text { method }\end{array}$ & $\begin{array}{l}\text { Path followed after } \\
\text { compaction }\end{array}$ & $\begin{array}{l}\text { Figure } \\
\text { number }\end{array}$ \\
\hline LP A1 & 1.427 & 27.10 & 81.16 & 580 & 4 & $\begin{array}{c}\text { Pressure } \\
\text { plate }\end{array}$ & Air: 1 week & $\begin{array}{l}\text { 1) Wetting to } 1 \mathrm{kPa} \\
\text { 2) Drying to } 600 \mathrm{kPa}\end{array}$ & Figure $6 a-f$ \\
\hline LT1 & $1.405^{\mathrm{a}}$ & 26.6 & 76.7 & 630 & 4 & Triaxial & Air: 1 week & $\begin{array}{l}\text { Wetting-drying (suction } \\
\text { cycle of } 500-0-550 \mathrm{kPa} \text { ) }\end{array}$ & Figure $6 a-f$ \\
\hline LT2 & $1.41^{\mathrm{a}}$ & 26.9 & 78.1 & 620 & 4 & Triaxial & Air: 1 week & $\begin{array}{l}\text { Wetting-drying (suction } \\
\text { cycle of } 500-0-550 \mathrm{kPa} \text { ) }\end{array}$ & Figure $6 a-f$ \\
\hline
\end{tabular}

a The target compaction dry density was $1.43 \mathrm{~g} / \mathrm{cm}^{3}$; the dry density value shown above reflects the swelling upon extraction from the mould

void ratios of the specimens compacted wet of optimum (see Fig. 5b) which experienced a higher shrinkage.

\subsection{Effect of stress state (mean net stress)}

Figure 6a-f shows comparative results of SWRC of limetreated specimens obtained from the pressure plate apparatus and the triaxial cell SWRC measurement method, both based on the axis translation technique. To better capture the details of the variation of each quantity, the scales of the axes representing $w$ and $S_{\mathrm{r}}$ were magnified (the axes do not start from zero values). Information on compaction characteristics, testing methods and hydromechanical paths followed is given in Table 6 .

There are clear differences in the SWRC obtained from the triaxial cell in terms of both $S_{\mathrm{r}}-s$ and $w-s$, (Fig. 6b, a, respectively); the degree of saturation of the pressure plate specimen is higher than that of the triaxial cell specimens, at least up to $200 \mathrm{kPa}$ of suction; this is due to the difficulty in saturating specimens subjected to a confining pressure (see Fig. 6a, b); in particular there is no noticeable maximum curvature point in the two triaxial testing specimens (there is very little variation in the $w$ or $S_{\mathrm{r}}$ within this suction range) unlike that of the pressure plate (see Fig. 6a, b); as expected, the deformation of specimen LT2-200 (200 $\mathrm{kPa}$ mean net stress) in both wetting and drying is considerably smaller than that of the specimen LT1-100 (100 kPa mean net stress; see Fig. 6c-e). Local LVDT measurements showed a very small change in void ratio $\Delta e(\Delta e=0.013$ and $\Delta e=0.001$ for the 100 and $200 \mathrm{kPa}$ net stresses, respectively) during ramped consolidation (resulting from the applied suction-net stress change increments). During the confined wetting path (Fig. 6c), the volume was maintained almost constant; this affects the SWRC compared with that of the pressure plate specimen (where no confining pressure is applied). A linear relationship between $S_{\mathrm{r}}$ and $w$ can be observed at the high water content range (nearly saturated conditions), where the difference in void ratios during drying and wetting is very small (Fig. 6c). Thus under the applied net stresses, the changes in the $S_{\mathrm{r}}-S$ curve are not a result of void ratio changes but mostly of gravimetric water content changes (Fig. 6 f shows a clear change in $S_{\mathrm{r}}$ with a change in $w$, while $e$ remains almost constant while $w$ changes, as shown in Fig. 6e). All wetting and drying curves show some degree of hysteresis, which is further discussed later.

\subsection{The effect of curing and testing conditions}

The results referring to curing conditions are initially plotted all together (Fig. 7a-f) to comment on the overall shape of the curves and whether these are affected by the different curing times and testing conditions. Due to the amount of data, some details of the curing time, curing methods and testing methods are plotted again separately for better clarity when focusing on each one of these effects individually (Figs. 8a-f, 9a-e). Information on compaction characteristics, testing methods and hydro-mechanical paths followed is given in Table 7.

\subsubsection{Effect of curing time}

Figure 7a-f shows that the effect of the curing time on the SWRC curves whether in terms of $S_{\mathrm{r}}-s$ or (especially) in terms of $w-s$ is found to be very small (see Figs. 7a-b, $8 \mathrm{c}$, e); this is true for both the drying and wetting curve sets coming from any method of testing or curing. Some differences can be noted mostly for the 8-month water-cured specimen. This appears to maintain higher degrees of saturation for a wider range of suctions /water contents, compared with the other specimens water-cured for shorter periods (see Fig. 7b, f). This is consistent with the overall lower void ratios of this specimen (see Fig. 7c, e). Note that from inspection of the $e-s$ and $e-w$ curves (see Fig. 7c, $\mathrm{e}$, respectively), there is a general indication that shrinkage appears to be taking place in particular for longer curing times (thus resulting in reduced void ratios), which is the opposite of what would have been expected. This is the 

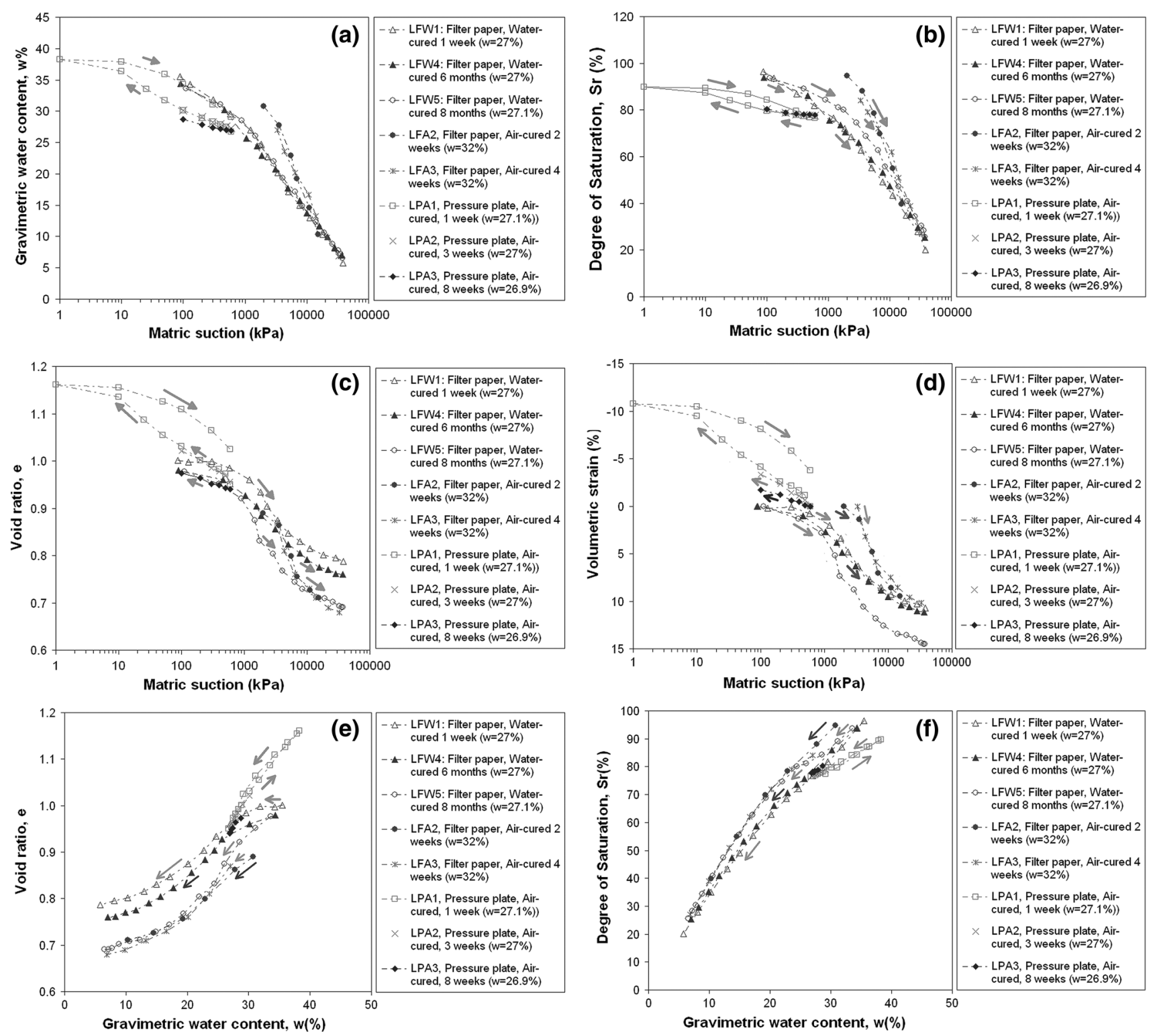

Fig. 7 Effect of curing; a gravimetric water content versus matric suction relationship; b degree of saturation versus matric suction relationship; c void ratio versus matric suction relationship; d volumetric strain with matric suction change; e void ratio versus gravimetric water content relationship; f degree of saturation versus gravimetric water content relationship

case for both the water-cured specimens and air-cured pressure plate specimens subject to wetting (see Figs. 7 , $8 \mathrm{~d}, \mathrm{f})$. However, with the exception of the 8-month watercured specimen the differences are very small. In addition, at the highest suction ranges, where water retention is predominantly linked to the micropores of the soil all $w$ $s$ and $S_{\mathrm{r}}-s$ sets of curves appear to essentially coincide (the observed differences are too small given the accuracy of the filter paper method).

Figure $7 \mathrm{~d}$ shows that the volumetric strains of the two filter paper specimens which were water-cured for 1 week and 6 months, respectively, are very close despite some differences in the void ratios of the two specimens
(Figs. 7c, 8d). Similarly, the differences in the volumetric strains between the 1- and 3-week air-cured specimens (pressure plate) are probably too small to be considered as significant. Indeed, it can be seen that for a suction of $100 \mathrm{kPa}$ upon wetting (where testing of two of the pressure plate specimens stopped), the volumetric strains measured during swelling were 3.3, 4.1 and $1.7 \%$ for the specimens air-cured for 1, 3 and 8 weeks, respectively (see Fig. 7d). Conversely the 8-month water-cured specimen shows a much more pronounced shrinkage deformation after a water content of about $25 \%$ (corresponding to suctions above $1000 \mathrm{kPa}$ ). As a result, the volumetric strain of the 8 -month water-cured specimen was $14.6 \%$, whereas those 

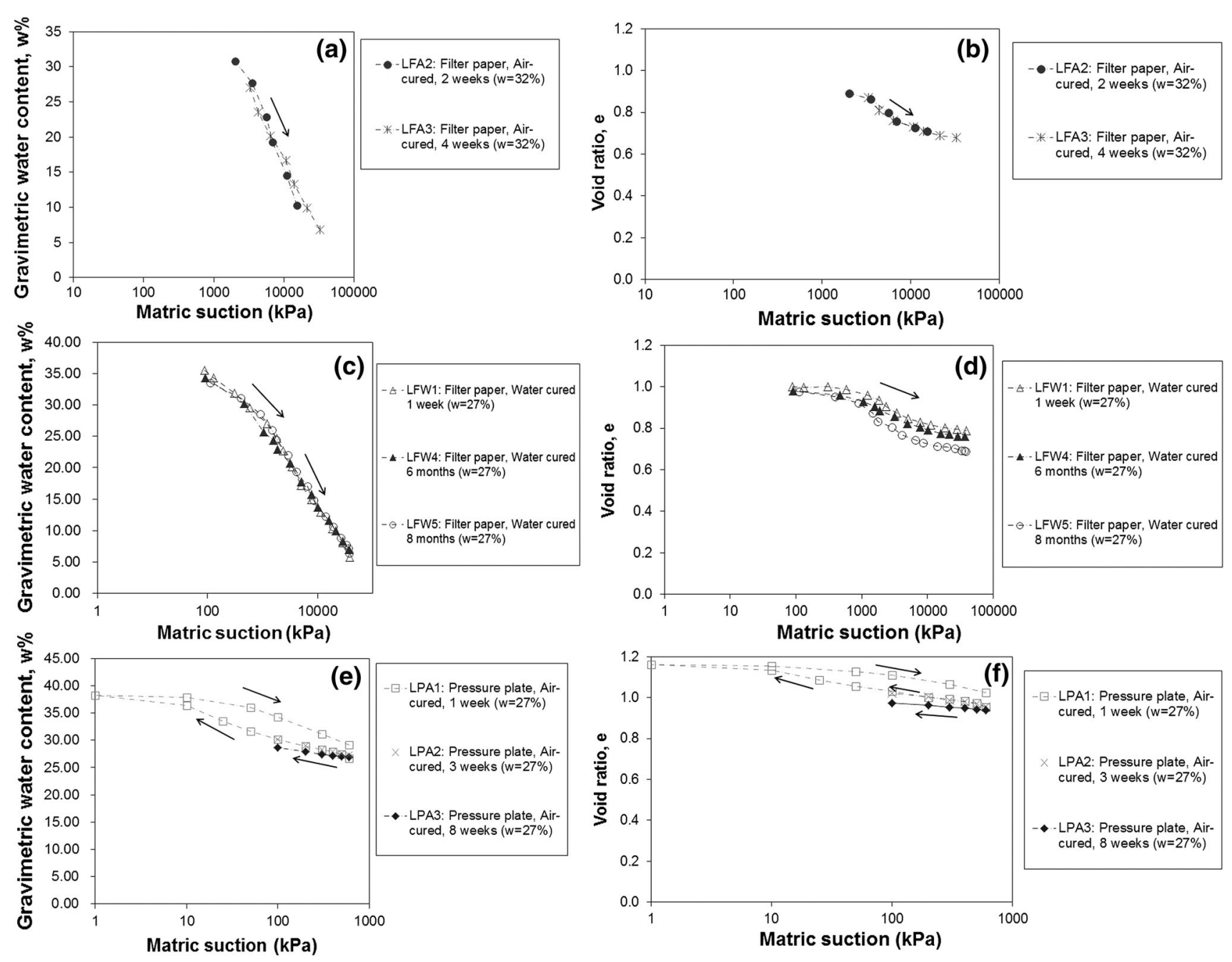

Fig. 8 Details of curing time comparisons: $\mathbf{a}-\mathbf{b}$ air-cured filter paper specimens; $\mathbf{c}-\mathbf{d}$ water-cured filter paper specimens; $\mathbf{e}-\mathbf{f}$ air-cured pressure plate specimens

of the 6-month and 1-week water-cured specimens were approximately the same (about $11 \%$ ).

The curves of the two filter paper air-cured specimens compacted at an initial water content of $32 \%$ and subjected to drying filter paper tests (specimens LFA2 and LFA3, respectively) are also very close showing again that curing time had little effect (see Figs. 7c-e, 8a-b). Note that these two specimens apparently show the lowest volumetric strains (Fig. 7d); however, it should not be concluded that these specimens had the best volumetric behaviour as these strains were obtained within a narrower range of suctions compared with the other specimens (testing started from as-compacted state without any wetting as opposed to the other specimens discussed in this section).

Overall, it can be concluded that with the exception of the 8-month water-cured specimen, all other groups of specimens show fairly consistent curves, indicating that the effect of curing time appears to be little, at least for this lime percentage used.

\subsubsection{Effect of curing method}

Concerning the curing method from Fig. 9a, it can be seen that the $w-s$ drying curves of the air and water-cured filter paper specimens LFA1 and LFW1 practically coincide. On the other hand, focusing on the $e-s$ and $e-w$ curves (Fig. 9c, d) it can be seen that the water-cured lime-treated specimen shows initially some slightly smaller changes in void ratio; however, after suctions higher than $1000 \mathrm{kPa}$, the curves of the water and air-cured lime-treated specimens coincide. It is possible that the slightly lower initial void ratios of the water-cured specimen in particular were an artefact of the small suction applied during water curing to facilitate saturation. Due to the lower void ratios and the higher (full) saturation achieved before starting the drying 

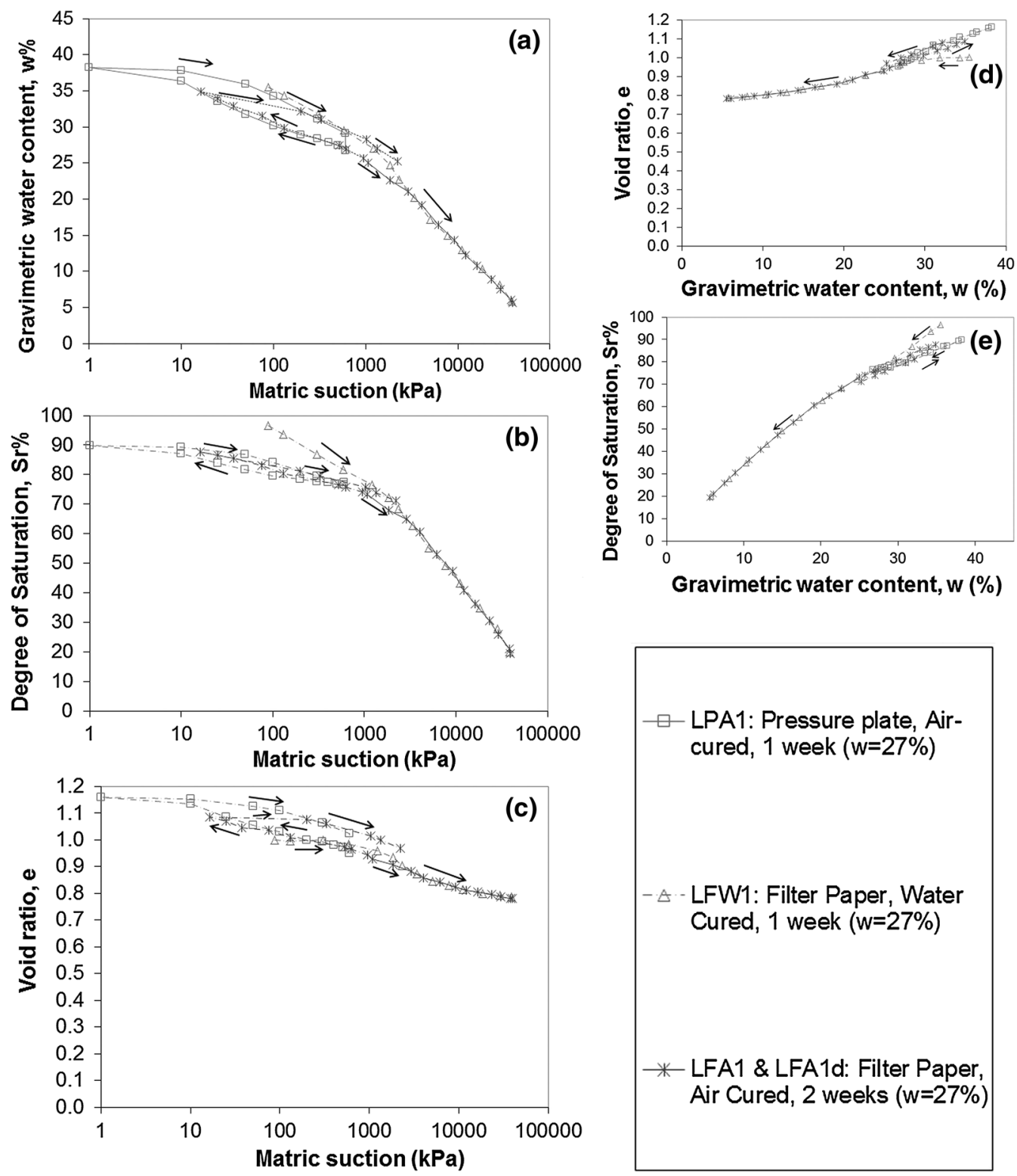

Fig. 9 Effect of curing and testing methods: a gravimetric water content versus matric suction relationship; b degree of saturation versus matric suction relationship; c void ratio versus matric suction relationship; d void ratio versus gravimetric water content relationship; e degree of saturation versus gravimetric water content relationship

test, the water-cured specimen $S_{\mathrm{r}}-S$ and $S_{\mathrm{r}}-w$ curves (Fig. 9b, e, respectively) start with higher degrees of saturation, but subsequently the air and water-cured specimens coincide at suctions higher than approximately $1000 \mathrm{kPa}$. This implies that the curing method had no effect on the microporosity of the soil.

\subsubsection{Effect of testing method}

The results presented in this section came from a combination of pressure plate and filter paper techniques, which could have led to differences in the results. Comparing the different testing method results in Fig. 7 and the details plotted in Fig. 9a-e, it can be seen that the $w-s$ curves of the 1-week air-cured pressure plate and both filter paper specimens essentially coincide in the common suction ranges for both wetting and drying (this is most clearly visible in the $w-s$ and $e-s$ curves shown in Fig. 9a, c). This is interesting as the two tests are carried out under different boundary conditions (in the pressure plate an elevated air pressure is used, whereas in the filter paper the air pressure is atmospheric). It is also notable that upon subsequent drying the 1-week air-cured specimen tested in the pressure plate recovered the $w-s$ curves of the filter paper specimens at higher suctions (subject to initial wetting). There are some very small differences around the reversal points 
Table 7 As-compacted specimen characteristics, test method and paths (effect of curing and testing conditions)

\begin{tabular}{|c|c|c|c|c|c|c|c|c|c|}
\hline $\begin{array}{l}\text { Specimen } \\
\text { ID }\end{array}$ & $\begin{array}{l}\text { Dry density } \\
\left(\mathrm{g} / \mathrm{cm}^{3}\right)\end{array}$ & $\begin{array}{l}\text { Water } \\
\text { content } \\
w \%\end{array}$ & $\begin{array}{l}\text { Degree of } \\
\text { saturation } \\
S_{\mathrm{r}} \%\end{array}$ & $\begin{array}{l}\text { Suction } \\
\mathrm{s}(\mathrm{kPa})\end{array}$ & Lime \% & $\begin{array}{l}\text { Test } \\
\text { method }\end{array}$ & Curing method & $\begin{array}{l}\text { Path followed after } \\
\text { compaction }\end{array}$ & $\begin{array}{l}\text { Figure } \\
\text { number }\end{array}$ \\
\hline LFW1 & 1.430 & 27.00 & 81.3 & 600 & 4 & Filter paper & Water: 1 week & $\begin{array}{l}\text { 1) Saturation } \\
\text { 2) Air drying } \\
\text { 3) Wetting }\end{array}$ & $\begin{array}{l}\text { Figure } 7 \mathrm{a}-\mathrm{f} \\
\text { Figure } 8 \mathrm{c}-\mathrm{d} \\
\text { Figure } 9 \mathrm{a}-\mathrm{e}\end{array}$ \\
\hline LFW4 & 1.432 & 27.00 & 81.48 & 610 & 4 & Filter paper & $\begin{array}{l}\text { Water: } \\
\quad 6 \text { months }\end{array}$ & $\begin{array}{l}\text { 1) Saturation } \\
\text { 2) Drying }\end{array}$ & $\begin{array}{l}\text { Figure } 7 \mathrm{a}-\mathrm{f} \\
\text { Figure } 8 \mathrm{c}-\mathrm{d}\end{array}$ \\
\hline LFW5 & 1.433 & 27.10 & 81.90 & 540 & 4 & Filter paper & $\begin{array}{l}\text { Water: } \\
8 \text { months }\end{array}$ & $\begin{array}{l}\text { 1) Saturation } \\
\text { 2) Drying }\end{array}$ & $\begin{array}{l}\text { Figure } 7 \mathrm{a}-\mathrm{f} \\
\text { Figure } 8 \mathrm{c}-\mathrm{d}\end{array}$ \\
\hline $\begin{array}{l}\text { LFA1 } \\
\quad \& \text { LFA1d }\end{array}$ & 1.43 & 27.00 & 81.2 & 600 & 4 & Filter paper & Air: 2 weeks & $\begin{array}{l}\text { LFA1: 1) Start wetting } \\
\text { 2) Drying LFA1d:Start } \\
\text { drying }\end{array}$ & $\begin{array}{l}\text { Figure } 7 a-f \\
\text { Figure } 9 a-e\end{array}$ \\
\hline LFA2 & 1.431 & 32.00 & 96.2 & $\mathrm{a}$ & 4 & Filter paper & Air: 2 weeks & $\begin{array}{l}\text { Drying to residual water } \\
\text { content }\end{array}$ & $\begin{array}{l}\text { Figure } 7 \mathrm{a}-\mathrm{f} \\
\text { Figure } 8 \mathrm{a}-\mathrm{b}\end{array}$ \\
\hline LFA3 & 1.43 & 32.00 & 96.1 & a & 4 & Filter paper & Air: 4 weeks & $\begin{array}{l}\text { Drying to residual water } \\
\text { content }\end{array}$ & $\begin{array}{l}\text { Figure } 7 \mathrm{a}-\mathrm{f} \\
\text { Figure } 8 \mathrm{a}-\mathrm{b}\end{array}$ \\
\hline LP A1 & 1.427 & 27.10 & 81.16 & 580 & 4 & Pressure plate & Air: 1 week & $\begin{array}{l}\text { 1) Wetting to } 1 \mathrm{kPa} \\
\text { 2) Drying to } 600 \mathrm{kPa}\end{array}$ & $\begin{array}{l}\text { Figure } 7 \mathrm{a}-\mathrm{f} \\
\text { Figure } 8 \mathrm{e}-\mathrm{f} \\
\text { Figure } 9 \mathrm{a}-\mathrm{e}\end{array}$ \\
\hline LP A2 & 1.428 & 27.00 & 80.99 & 580 & 4 & Pressure plate & Air: 3 weeks & 1) Start wetting & $\begin{array}{l}\text { Figure } 7 \mathrm{a}-\mathrm{f} \\
\text { Figure } 8 \mathrm{e}-\mathrm{f}\end{array}$ \\
\hline LP A3 & 1.431 & 26.92 & 81.12 & 580 & 4 & Pressure plate & Air: 8 weeks & 1) Start wetting & $\begin{array}{l}\text { Figure } 7 \mathrm{a}-\mathrm{f} \\
\text { Figure } 8 \mathrm{e}-\mathrm{f}\end{array}$ \\
\hline
\end{tabular}

${ }^{\mathrm{a}}$ Missing measurement

(from drying to wetting) in the low suction ranges visibly mostly in the $S_{\mathrm{r}}-s$ and $S_{\mathrm{r}}-w$ curves (Fig. 9b, e, respectively) and in the second place the $e-s$ and $e-w$ curves (Fig. 9c, d, respectively). These could possibly be attributed to the fact that in the low range of suctions before air-entry value axis translation technique reliability can be affected as air is in occluded form. It is arguable, however, whether these differences can be considered as significant.

Overall, inspecting all results plotted in Fig. 7 together and the details shown in Figs. 8 and 9, it can be concluded that the differences between the different curves are small and consequently so is the effect of the different curing conditions and testing techniques.

\subsection{Hysteresis effects}

The presented results refer to filter paper specimens CF5, LFA1 and LFW1 as well as pressure plate specimens CP1 and LPA1 prepared consistently at the same dry density (of approximately $1.43 \mathrm{~g} / \mathrm{cm}^{3}$ - the maximum density corresponding to the standard Proctor Optimum of the untreated soil) and saturated using back pressure. The only difference was that whereas the untreated soil had a moisture content of $25 \%$ (dry of the Proctor optimum), for the lime-treated specimens an extra $2 \%$ water content was used (still on the dry side of the Proctor optimum of the treated soil), to ensure that enough water was present for the chemical reactions (considering the higher optimum water content of the treated soil according to the Proctor test). Information on compaction characteristics, testing methods and hydromechanical paths followed is given in Table 8 .

According to Fig. 10a-c, both the untreated and treated soils show hysteresis, regardless of the method of testing. Note that the air-cured specimens were not wetted as the water-cured ones were and for this reason they have an apparent smaller hysteresis in the $S_{\mathrm{r}}-S$ curves. For the untreated specimen, there are some differences between pressure plate and filter paper results around the reversal points (from drying to wetting) possibly because in the low range of suctions before air-entry value (a zone which is extended for the untreated soil) axis translation technique reliability can be affected as air is in occluded form. The $e-$ $s$ curves of both the treated and untreated specimens show hysteresis denoting irrecoverable deformation after drying (see Fig. 10c). However, the overall void ratio change with suction upon both wetting and drying is clearly higher for the untreated soil (as also noted earlier). This confirms the improvement in the volumetric stability of the treated soil upon cycles of drying and wetting. Thus the $e-s$ and $e-w$ plots of the treated soil (Fig. 10c, d) show only a small change in $e$ in both drying and subsequent re-wetting; the suction range within which there is little void ratio change is much wider for 
Table 8 As-compacted specimen characteristics, test method and paths (hyseresis effects)

\begin{tabular}{|c|c|c|c|c|c|c|c|c|c|}
\hline $\begin{array}{l}\text { Specimen } \\
\text { ID }\end{array}$ & $\begin{array}{l}\text { Dry density } \\
\left(\mathrm{g} / \mathrm{cm}^{3}\right)\end{array}$ & $\begin{array}{l}\text { Water } \\
\text { content } \\
w \%\end{array}$ & $\begin{array}{l}\text { Degree of } \\
\text { saturation } S_{\mathrm{r}} \%\end{array}$ & $\begin{array}{l}\text { Suction s } \\
(\mathrm{kPa})\end{array}$ & $\begin{array}{l}\text { Lime } \\
\%\end{array}$ & $\begin{array}{l}\text { Test } \\
\text { method }\end{array}$ & $\begin{array}{l}\text { Curing } \\
\text { method }\end{array}$ & $\begin{array}{l}\text { Path followed after } \\
\text { compaction }\end{array}$ & Figure number \\
\hline CF5 & 1.43 & 25.23 & 75.3 & 650 & 0 & $\begin{array}{l}\text { Filter } \\
\text { paper }\end{array}$ & N/A & $\begin{array}{l}\text { 1) Saturation } \\
\text { 2) Drying to residual } \\
\text { water content } \\
\text { 3) Wetting }\end{array}$ & $\begin{array}{l}\text { Figure } 10 \mathrm{a}-\mathrm{e} \\
\text { Fig. } 11 \\
\text { Fig. } 12 \\
\text { Fig. } 14\end{array}$ \\
\hline $\mathrm{CP} 1$ & 1.431 & 25.36 & 75.62 & 660 & 0 & $\begin{array}{l}\text { Pressure } \\
\text { plate }\end{array}$ & N/A & $\begin{array}{l}\text { 1) Saturation } \\
\text { 2) Drying to } 600 \mathrm{kPa} \\
\text { 3) Wetting to } 1 \mathrm{kPa}\end{array}$ & Figure 10a-e \\
\hline LFW1 & 1.430 & 27.00 & 81.3 & 600 & 4 & $\begin{array}{l}\text { Filter } \\
\text { paper }\end{array}$ & $\begin{array}{l}\text { Water: } \\
1 \text { week }\end{array}$ & $\begin{array}{l}\text { 1) Saturation } \\
\text { 2) Air drying } \\
\text { 3) Wetting }\end{array}$ & $\begin{array}{l}\text { Figure } 10 \mathrm{a}-\mathrm{e} \\
\text { Fig. } 11 \\
\text { Fig. } 12 \\
\text { Fig. } 14\end{array}$ \\
\hline $\begin{array}{l}\text { LFA1 \& } \\
\text { LFA1d }\end{array}$ & 1.43 & 27.00 & 81.2 & 600 & 4 & $\begin{array}{l}\text { Filter } \\
\text { paper }\end{array}$ & $\begin{array}{l}\text { Air: } \\
2 \text { weeks }\end{array}$ & $\begin{array}{l}\text { LFA1: 1) Start } \\
\text { wetting } \\
\text { 2) Drying } \\
\text { LFA1d:Start drying }\end{array}$ & Figure $10 \mathrm{a}-\mathrm{e}$ \\
\hline LP A1 & 1.427 & 27.10 & 81.16 & 580 & 4 & $\begin{array}{l}\text { Pressure } \\
\text { plate }\end{array}$ & $\begin{array}{l}\text { Air: } \\
\quad 1 \text { week }\end{array}$ & $\begin{array}{l}\text { 1) Wetting to } 1 \mathrm{kPa} \\
\text { 2) Drying to } 600 \mathrm{kPa}\end{array}$ & Figure $10 \mathrm{a}-\mathrm{e}$ \\
\hline
\end{tabular}

the treated compared with the untreated soil, consistent with the fact that the former soil is less prone to shrinking/swelling. This is also reflected in the $S_{\mathrm{r}}-w$ curve of the treated soil (Fig. 10e) which shows that the relationship between the degree of saturation and the gravimetric water content is linear within a wider range of water contents than it is for the untreated soil. Referring to the known relationship $S_{\mathrm{r}}$ $e=w G_{\mathrm{s}}$, the linearity is linked to the small variations in the $e$ value; if this is almost constant, a direct proportionality between $S_{\mathrm{r}}$ and $w$ is implied. Considering this and the fact that the $S_{\mathrm{r}}-s$ and $w-s$ curves (Fig. 10b, a, respectively) show an hysteresis from the very onset of wetting for both soils, it can be inferred that at high suctions hysteresis is linked primarily to hydraulic factors (as there is no $e-s$ hysteresis initially-see Fig. 10c); this is more pronounced for the treated soil. It can be noted that the $S_{\mathrm{r}}-s$ and $w-s$ hysteresis loops of the two soils are of similar width. This statement can be further supported by the $e-w$ plots (Fig. 10d); these curves present little hysteresis for the treated soil, whereas there is a clear hysteresis for the untreated soil showing the difference in void ratio change with water content during shrinkage and drying.

\section{Discussion}

The analysis of the experimental results presented above highlighted some interesting features on the effect of water retention and volumetric behaviour of the soil: (a) First, curing method and time had little effect on the results. Similar observations on the curing time were made in
Cuisinier et al. [12] who concluded that the main effects appear to be due to compaction and immediate reactions. This is consistent with the UU testing results of the presented research reported earlier. However, this finding cannot be generalised, as for a higher lime percentages (not reported here) the curing time effect may have been more pronounced due to continuing pozzolanic reactions; (b) secondly, it was observed that lime appears to have affected primarily the macrostructure of the soil but had little effect on its microstructure ${ }^{1}$ which was not expected; (c) little difference was noted in the gravimetric content changes with suction of the treated soil compared to the untreated soil, whereas clear differences in the volume change of the two soils were noted; hence, the differences in the water retention of the soil in terms of plots of degree of saturation changes appear to be mostly due to effects of lime on the volumetric properties of the soil. The latter two findings will now be further supported by a number of additional comparative plots and SEM analysis.

First, for a clearer direct comparison between the results relating to the two different soils (untreated soil and limetreated soil), in view of the different ranges of values of the

\footnotetext{
${ }^{1}$ A note that should be made here is that the use of the term 'microstructure' has not been consistent in the literature as it could be used to denote either (a) 'the elementary particle associations within the soil aggregates' (i.e. the smaller pores, referred to as intraaggregate pores), as opposed to 'macrostructure' ('the arrangement of the soil aggregates and the relation between the structural units at the aggregate level' $[1,22]$ (i.e. the larger pores referred to as interaggregate pores) or (b) the features of the soil at the particle/aggregate scale. In this paper, the former definition of the term is used.
} 

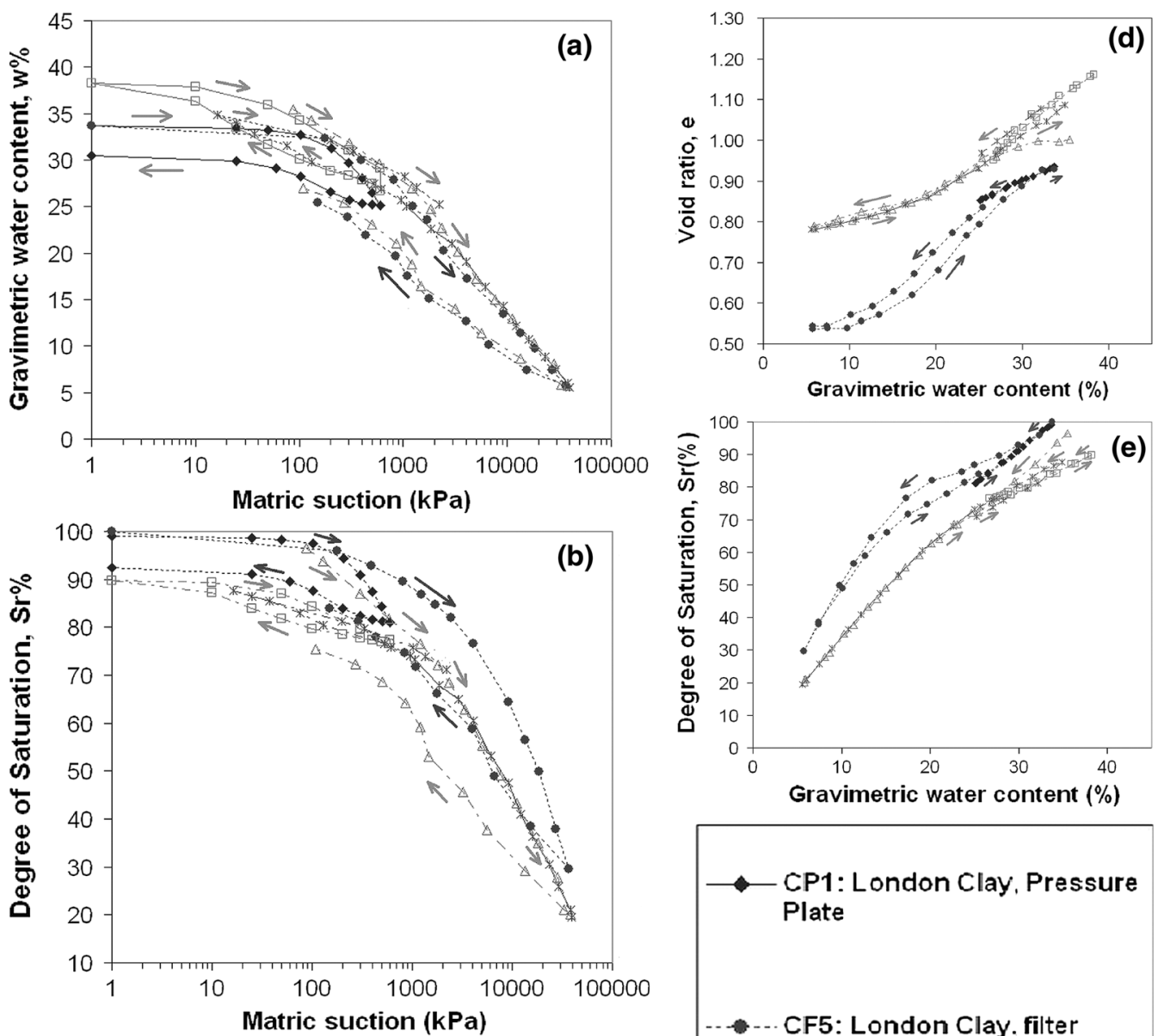

(e)

Gravimetric water content $(\%)$

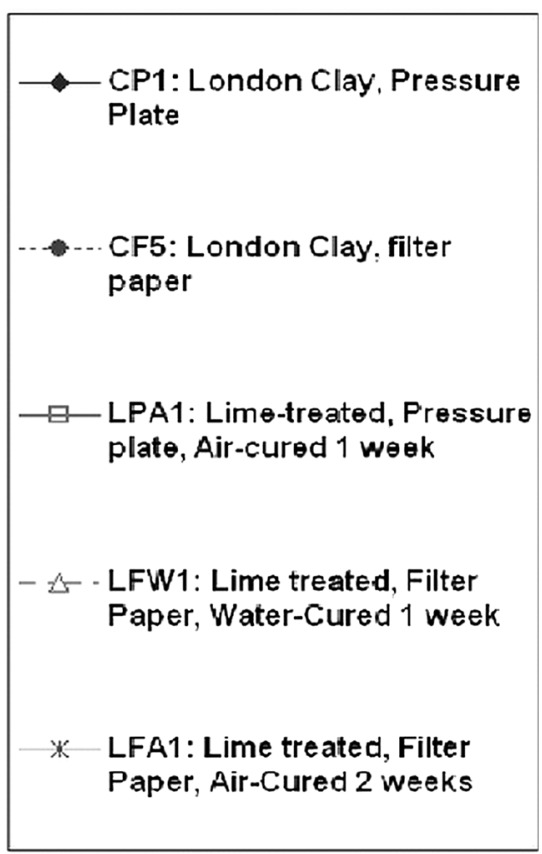

Fig. 10 Comparative wetting and drying curves of the untreated and treated soils: a gravimetric water content versus matric suction relationship; b degree of saturation versus matric suction relationship; c void ratio versus matric suction relationship; d void ratio versus gravimetric water content relationship; e degree of saturation versus gravimetric water content relationship

variables plotted for each soil, normalised quantities are represented to confirm the above interpretation of the data. For the normalised curves, the results of two filter paper specimens were plotted, namely CF5 and LFW1 for the untreated and lime-treated soil, respectively. These specimens were chosen because they were consistently prepared and saturated and covered a wide range of degrees of saturation starting by nearly saturated conditions. The normalised quantities plotted were the effective degree of saturation $S_{\mathrm{e}}=\left(S_{\mathrm{r}}-S_{\mathrm{rres}}\right) /\left(1-S_{\mathrm{res}}\right)$, the normalised gravimetric water content $w_{\text {norm }}=\left(w-w_{\min }\right) /\left(w_{\max }-w_{\min }\right)$ and the volumetric strains (see Fig. 11a-c, respectively). 

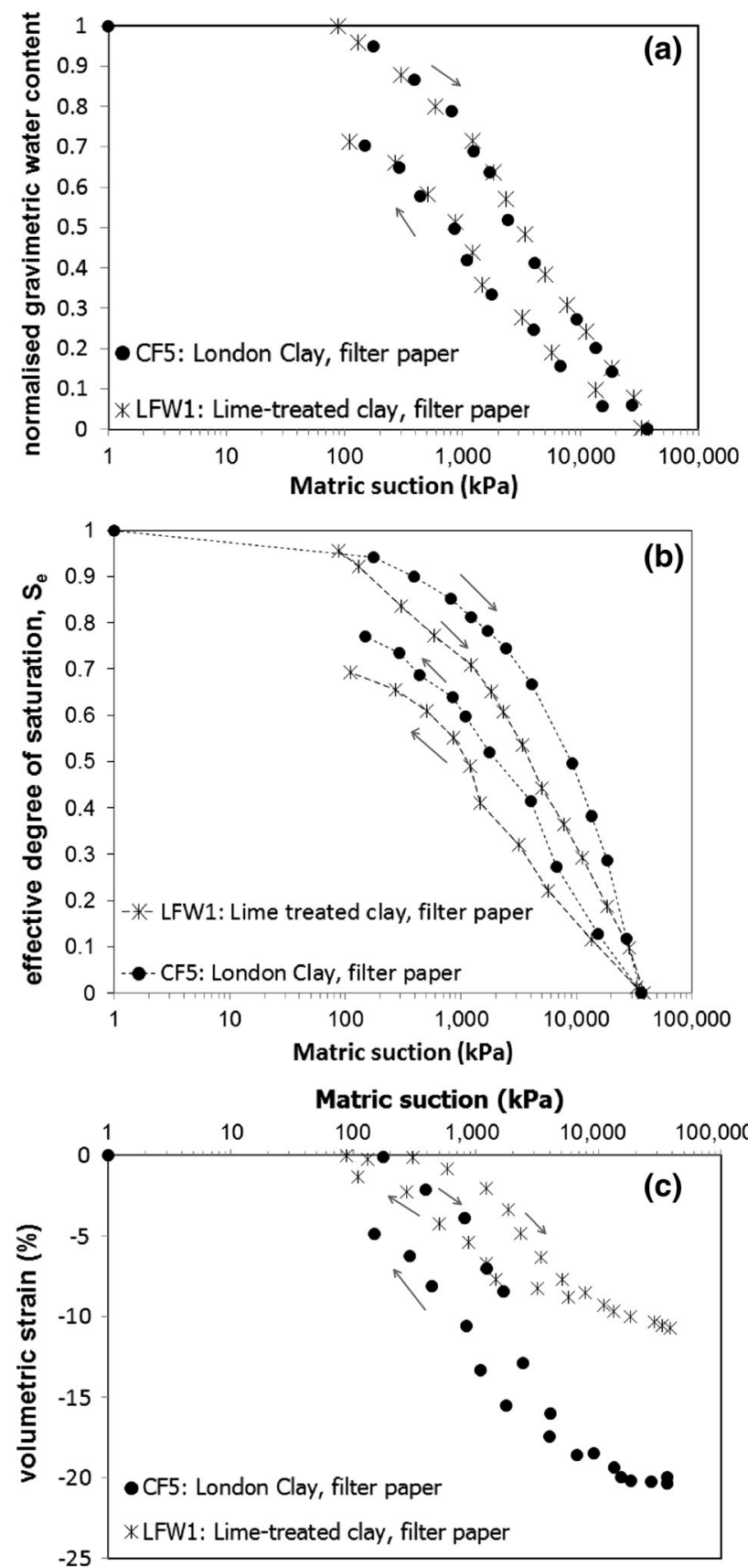

Fig. 11 Normalised curves of the untreated and treated soils: a normalised gravimetric water content versus matric suction; b normalised (effective) degree of saturation versus matric suction; c volumetric strain versus suction plots

From the normalised results of the $S_{\mathrm{e}}$ curves, it can be seen that the untreated soil maintains a higher saturation than the treated soil throughout the testing. As shown also in the original data before normalisation (Fig. 10), there are some small differences in the rate of desorption/absorption of the two soils (with the treated soil showing slightly lower rates) but it is arguable whether these are significant. On the other

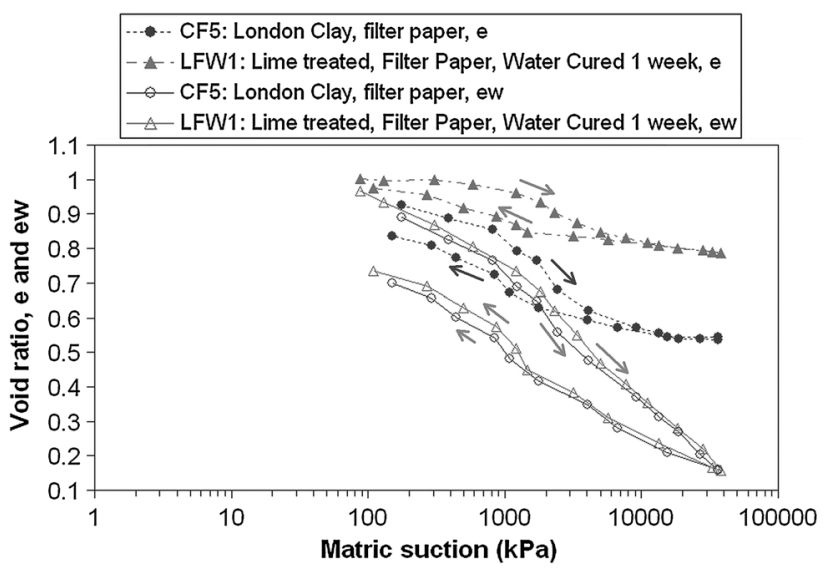

Fig. 12 Comparative plots of void ratio $e$, and water void ratio $e_{w}$ versus suction

hand, the normalised water content curves of the two soils practically coincide. This is not the case of the volumetric strains which are clearly different for the two soils, with the treated soil shown to experience reduced volume changes compared with those of the untreated one. This clearly confirms that the differences in the water retention noted (represented by the $S_{\mathrm{e}}$ curves) are predominantly due to strain-related quantities due to the increased stiffness and volumetric stability of the lime-treated soil.

Furthermore, for the same specimens (CP5 and LWF1) comparative plots of the water void ratio $e_{w}$ versus suction curves together with the void ratio $e-s$ curves are shown in Fig. $12[15,43]$. If the specimen is saturated, the $e_{w}$ and $e$ would coincide; it can thus be seen that at the start of drying the two ratios are very closely located for both soils indicating nearly saturated conditions. Henceforth, the respective two curves $\left(e-s\right.$ and $\left.e_{w}-s\right)$ for both soils separate as the $e-s$ curve gradient reduces, while the soil is heading towards its shrinkage limit, whereas the $e_{w}-s$ curve gradient remains unaltered with the specimen losing water without a similar rate in void volume change. It is notable that at the end of the testing the $e_{w}-s$ curve of either soil did not reach a constant value, which would correspond to residual moisture content conditions. Whereas both soils show the same trends, it is notable that the separation between the two curves $\left(e-s\right.$ and $\left.e_{w}-s\right)$ is more pronounced for the lime-treated soil, which is less prone to volume change and which also approaches its shrinkage limit faster than the untreated soil. On the other hand, it can be seen that the $e_{w}-s$ curves for both the treated and the untreated soil are located very close and are similar in form (practically coinciding considering the initial differences in void ratios and the usual scatter of the experimental results) with the same gradient for both drying and wetting. This clearly shows that void ratio changes aside, the rates of losses in water volume for the two soils remain practically 

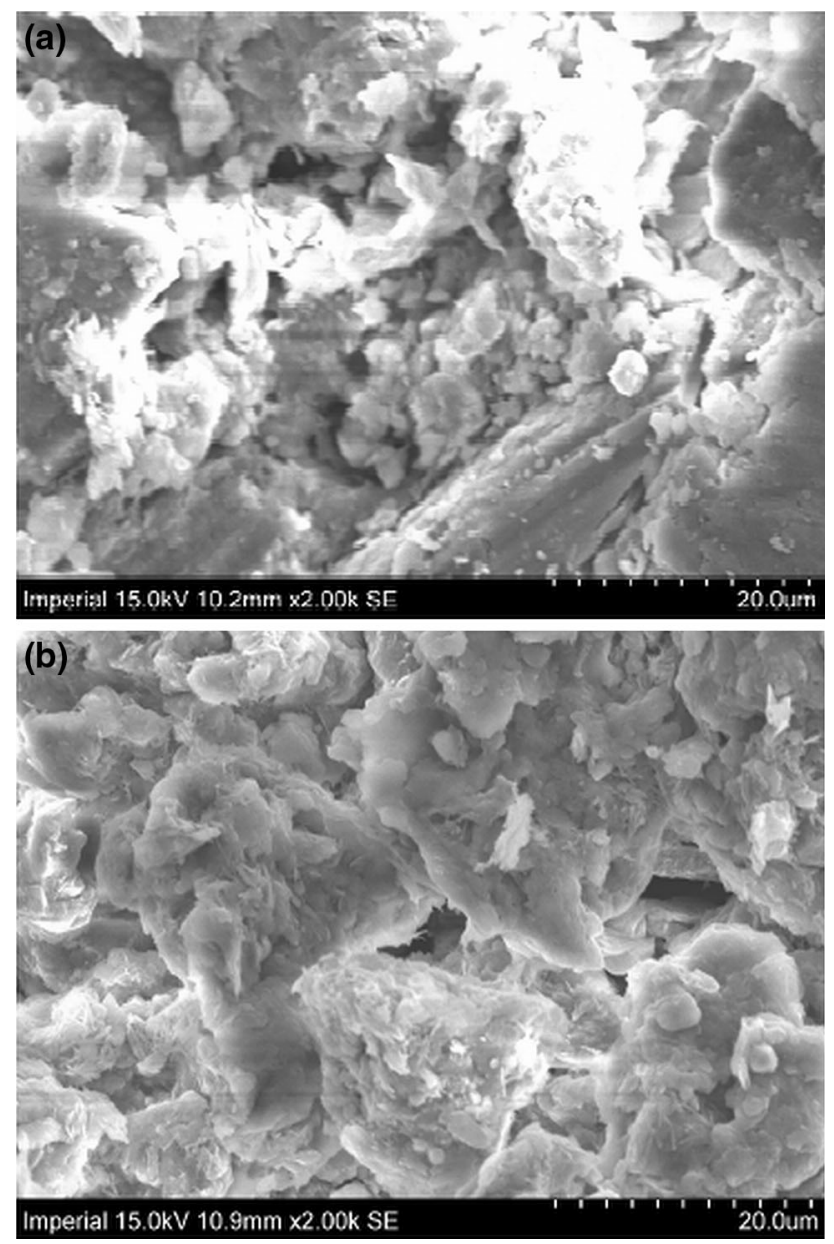

Fig. 13 Comparative SEM pictures a London Clay; b lime-treated London Clay

unaltered by the addition of lime. This supports the observation that the effects of lime addition on the SWRC of the soil relate predominantly to changes in the deformability of the soil.

As noted earlier, the air-entry value of the untreated soil was higher than that of the treated soil. This was attributed to the more open structure of the lime-treated soil. This statement can be further supported by SEM pictures of the two soils (treated and untreated, Fig. 13a, b, respectively). From the SEM pictures, it can be seen that the compacted specimens have a bimodal fabric containing both inter-aggregate and intra-aggregate pores. From the SEM picture of the lime-treated sample, the flocculation and aggregation of the particles can be observed; larger pore radii compared with the untreated soil can also be seen; this supports the assumption of a more open structure and justifies the lower air-entry values of the treated soil.
Although air-entry value is affected by the lime treatment process, in Fig. 11 the difference in the slopes of the respective drying and wetting curves beyond the points of maximum curvature is small, implying that there is little change in the rate of desorption or absorption upon lime addition in the higher suction ranges, where water retention is linked to the micropores of the soil. This finding was unexpected, as water retention at high suctions is mainly governed by the physicochemical interactions between water and the clay itself; it was thought that chemical changes could have significantly affected these. However, this was consistently observed throughout the presented set of specimens (see Sect. 4) and can be further supported by the mathematical fitting of the $S_{\mathrm{r}}-s$ curves of the filter paper specimens CF5 and LFW1 for the untreated and lime-treated soil, respectively, which span through the whole range of degrees of saturation, starting from nearly saturated conditions. These were back-fitted by a continuous mathematical expression according to van Genuchten's relationship [44], using the commercial software EasyPlot (see Fig. 14). In terms of degree of saturation $S_{\mathrm{r}}$, this relationship is written as:

$S_{r}=S_{\text {res }}+\left(1-S_{\text {res }}\right)\left\{\frac{1}{1+\left[\alpha\left(u_{a}-u_{w}\right)\right]^{n}}\right\}^{m}$

where $S_{r_{\text {res }}}$ is the residual degree of saturation (here assumed to be equal to $1 \times 10^{-4}$ for the curve-fitting purposes) and $a, n$ and $m$ are curve-fitting parameters, often related, respectively, to the air-entry value, pore size distribution of the soil and the asymmetry of the model [39].

The exact values of the parameters show some sensitivity to the assumed maximum resaturation value of $S_{\mathrm{r}}$, but the trends remain the same regardless of this value. In the presented analysis, resaturation $S_{\mathrm{r}}$ values of 92.5 and $90 \%$ were assumed for the untreated and treated soils, respectively, based on Fig. 10b (it was shown that full resaturation was not obtainable).

From the fitting parameters for the two soils given in Table 9, it can be confirmed that the air-entry values of the two soils upon desorpion differ by three orders of magnitude (based on the value of the parameter $a$ ) with the lime-treated soil having clearly a much lower air-entry value; conversely, the parameter $n$ linked to the rate of desaturation after the airentry point indeed differs very little between the two soils (untreated versus lime treated) as observed earlier by visual inspection. On the other hand, the differences in the wetting curves are less pronounced; the value of the parameter $\alpha$ differs now only slightly and the slope of the curves as well as the overall shape denoted by the parameters $n$ and m, respectively, appears to be very similar. 


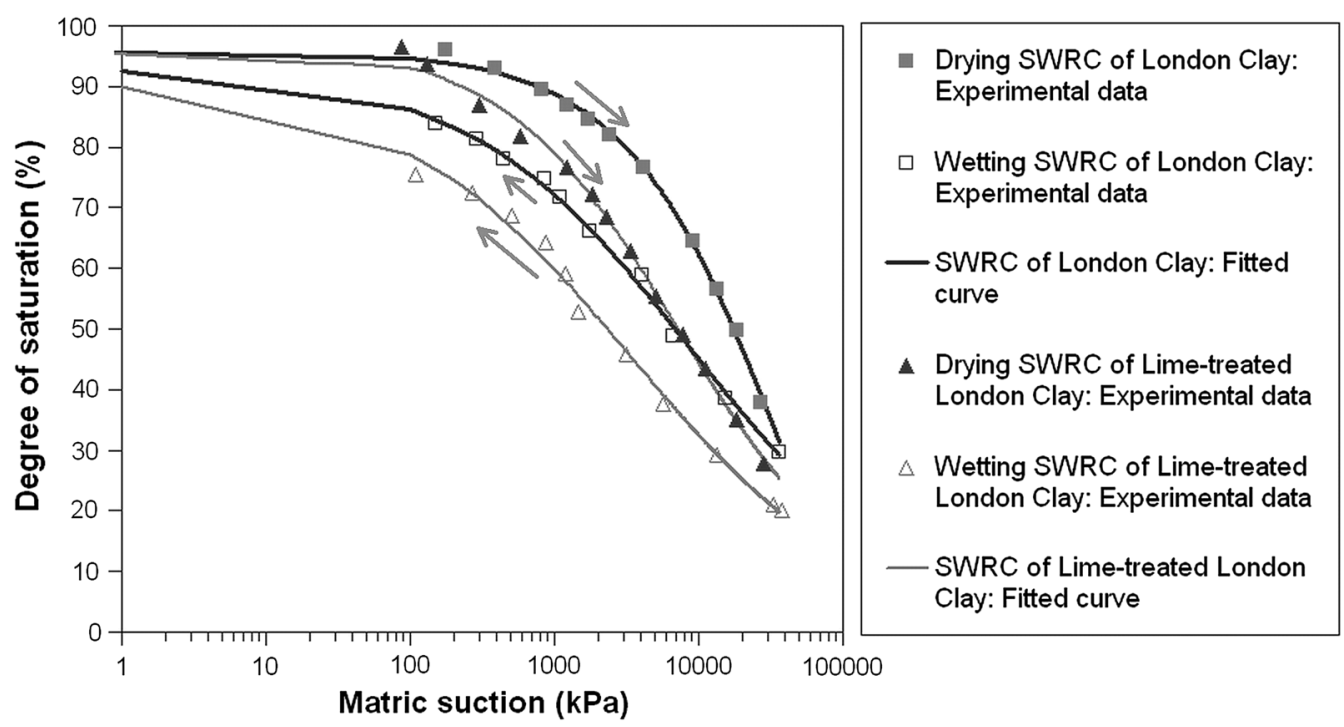

Fig. 14 Comparative results of London Clay and lime-treated London Clay, fitted by van Genuchten's model [44]

Table 9 Comparative SWRC curve-fitting using van Genuchten's model [44]

\begin{tabular}{llll}
\hline Soil & $\alpha\left(\mathrm{kPa}^{-1}\right)$ & $n$ & $m$ \\
\hline $\begin{array}{l}\text { Untreated London Clay } \\
\quad(\mathrm{CF} 5) \text {-drying }\end{array}$ & $1.19 \times 10^{-7}$ & 0.743 & 64.111 \\
$\begin{array}{l}\text { Lime-treated London Clay } \\
\quad(\mathrm{LF} 1) \text {-drying }\end{array}$ & $2.08 \times 10^{-4}$ & 0.768 & 0.765 \\
$\begin{array}{l}\text { Untreated London Clay } \\
\quad(\mathrm{CF} 5) \text {-wetting }\end{array}$ & $1.37 \times 10^{-4}$ & 0.584 & 0.91 \\
$\begin{array}{l}\text { Lime-treated London Clay } \\
\text { (LFA1)—wetting }\end{array}$ & $3.18 \times 10^{-4}$ & 0.552 & 0.958 \\
\hline
\end{tabular}

\section{Conclusions}

This paper investigated the water retention behaviour and corresponding volume change upon wetting and drying of a compacted high plasticity clay (London Clay) treated with lime. A series of drying and/or wetting tests were conducted based on three different testing methodologies to determine the SWRC; these investigated the effect of a number of factors potentially influencing the SWRC. The main findings were as follows:

- The effect of initial (as compacted) dry density and water content on the form of the lime-treated soil SWRC as well as the soil volume change behaviour upon wetting and drying was consistent with findings in the literature regarding the effect of such factors on compacted untreated soils. Namely compaction water content was more influential than density, but the SWRC was found to be unique in the high range of soil suctions in which adsorptive forces are predominant.
- As with untreated soils, a clear hysteresis was observed between wetting and drying SWRC. Higher confinement pressures have affected the overall shape of the SWRC even for the stiffer chemically treated soil.

- Filter paper and pressure plate results were consistent despite the different boundary conditions imposed.

- Concerning differences between the treated and corresponding untreated clay specimens, it was shown that the effect of treatment on the water retention of the soil was mostly observed in terms of a reduced air-entry value (AEV), implying a lower water retention at low suctions; conversely, when inspecting the rates of water absorption/desorption of the treated and untreated soils at higher suctions where adsorptive forces predominate the differences were surprisingly found to be very small. The lime-treated soil showed clearly lower volumetric strains upon drying or wetting throughout all range of suctions, compared with the untreated London Clay, although some irrecoverable deformation upon wetting and drying was noted for both soils. However, overall the lime-treated soil showed a clearly improved volumetric response when subject to moisture content changes.

Based on these observations, it can be concluded that overall the lime-induced chemical changes in the soil structure considerably affected predominantly the strainrelated quantities (the void ratio and the volumetric strain) due to the increased stiffness and that any consequent apparent differences in the soil water retention result mainly from this effect. Although the lime treatment led to a clear improvement in the volumetric stability of the originally shrinkable clay soil upon water content changes, the volume change response and water retention behaviour 
of the soil in the long-term after multiple drying-wetting cycles need some further investigation.

Acknowledgments The experimental study presented in this paper was funded by the UK Engineering and Physical Sciences Research Council (EPSRC) through grant EP/E037305/1. All results were produced by the first author during his doctoral studies at London South Bank University under the co-authors' supervision, except for one set of results, which was taken from the final year dissertation of Mr Luke Katchoff [19], supervised by the second author.

Open Access This article is distributed under the terms of the Creative Commons Attribution 4.0 International License (http:// creativecommons.org/licenses/by/4.0/), which permits unrestricted use, distribution, and reproduction in any medium, provided you give appropriate credit to the original author(s) and the source, provide a link to the Creative Commons license, and indicate if changes were made.

\section{References}

1. Al-Mukhtar M, Belanteur N, Tessier D, Vanapalli SK (1996) The fabric of clay soil under controlled mechanical and hydraulic stresses. Appl Clay Sci 11(2-4):99-115

2. Alonso EE, Pinyol NM (2008) Unsaturated soil mechanics in earth and rockfill dam engineering. In: Toll DG, Augarde CE, Gallipoli D, Wheeler SJ (eds) Unsaturated soils: advances in geoengineering, proceedings of the 1st European conference on unsaturated soils, E-UNSAT 2008, Durham, UK, July 2-4, 2008. CRC Press, London, pp 3-32

3. Al-Rawi NM, Awad AAA (1981) Permeability of lime-stabilized soils. Proc ASE Transp Eng Div 107(1):25-35

4. American Society for Testing and Materials (1994) ASTM D 5298: 1994. Standard Test Method for Measurement of Soil Potential (Suction) Using Filter Paper, West Conshohocken, PA 19428, ASTM

5. Baker R, Frydman S (2009) Unsaturated soil mechanics. Critical review of physical foundations. Eng Geol 106(1):26-39

6. Barbour LS (1998) Nineteenth Canadian Geotechnical Colloquium: the soil-water characteristic curve: a historical perspective. Can Geotech J 35:873-894

7. Bell FG (1988) Lime stabilization of clay soils: part 1, basic principles. Ground Eng 21(1):10-15

8. Casini F, Vaunat J, Romero E, Desideri A (2012) Consequences on water retention properties of double-porosity features in a compacted silt. Acta Geotechnica 7(2):139-150

9. Cecconi M, Russo G (2013) Microstructural features of limestabilised pyroclastic soils. Géotech Lett 3(3):124-129

10. Chandler RJ, Gutierrez CL (1986) The filter paper method of suction measurement. Géotechnique 36(2):265-268

11. Cui YJ, Tang AM, Loiseau C, Delage P (2008) Determining the unsaturated hydraulic conductivity of a compacted sand-bentonite mixture under constant volume and free-swell conditions. Phys Chem Earth 33(Suppl. 1):462-471

12. Cuisinier O, Masrouri F, Stoltz G, Russo G (2014) Multi-scale analysis of the swelling and shrinkage of a lime-treated expansive clayey soil. In: Khalili $\mathrm{N}$ et al (eds) Unsaturated soils: research and applications. Taylor \& Francis, London, pp 441-447

13. Della Vecchia G, Dieudonné AC, Jommi C, Charlier R (2015) Accounting for evolving pore size distribution in water retention models for compacted clays. Int J Numer Anal Methods Geomech 39:702-723
14. Di Sante M, Fratalocchi E, Mazzieri F, Pasqualini E (2014) Time of reactions in a lime treated clayey soil and influence of curing conditions on its microstructure and behavior. Appl Clay Sci 99:100-109

15. Dineen K (1997) The influence of soil suction on compressibility and swelling. PhD Thesis, University of London

16. Eades JL, Grim RE (1966) A quick test to determine lime requirements for soil stabilization. Transportation Research Board, Washington, DC Highway Research Record No. 139, pp $61-72$

17. Fredlund DG, Rahardjo H (1993) Soil mechanics for unsaturated soils. Wiley, New York

18. Jotisankasa A (2005) Collapse behaviour of a compacted silty clay. Ph.D. thesis, Imperial College, London, UK

19. Katchoff L (2011) An investigation into the soil-water retention Curve of Natural London Clay and Lime Stabilised London Clay. Final year project dissertation, London South Bank University

20. Khattab S, Al-Taie L (2006) Soil-water characteristic curves (SWCC) for lime treated expansive soil from Mosul City. In: Unsaturated soils: 4th international conference on unsaturated soils (UNSAT 2006), ASCE, pp 1671-1682

21. Khattab S, Al-Mukhtar M, Fleureau J (2007) Long-term stability characteristics of a lime-treated plastic soil. J Mater Civ Eng 19(4):358-366

22. Koliji A, Laloui L, Cusinier O, Vulliet L (2006) Suction induced effects on the fabric of a structured soil. Transp Porous Media 64(2):261-278

23. Koliji A, Lehmann P, Vulliet L, Laloui L, Carminati A, Vontobel $\mathrm{P}$, Hassanein R (2008) Assessment of structural evolution of aggregated soil using neutron tomography. Water Resour Res 44:W00C07. doi:10.1029/2007WR006297

24. Luis A, Marcial D (2013) Water retention properties of a residual soil from Caracas. In: Caicedo B et al (eds) Advances in unsaturated soils. Taylor \& Francis Group, London, pp 249-252

25. Mavroulidou M, Zhang X, Cabarkapa Z, Gunn MJ (2009) A study of the laboratory measurement of the Soil Water Retention Curve, 11th international conference on the environmental science and technology (CEST2009), 3-5 Sept 2009, Chania, Greece (online) http:// www.srcosmos.gr/srcosmos/. Last accessed: $04 / 10 / 2013$

26. Mavroulidou M, Cabarkapa Z, Gunn MJ (2013) Efficient laboratory measurements of the soil water retention curve. Geotech Test J 36(1):1-9

27. Mavroulidou M, Zhang X, Gunn MJ, Cabarkapa Z (2013) Water retention and compressibility of a lime-treated, high plasticity clay. Geotech Geol Eng 31(4):1171-1185

28. Melgarejo-Corredor M (2004) Laboratory and numerical investigations of soil retention curves. Ph.D. thesis, Imperial College of Science, Technology and Medicine, University of London

29. Metelková Z, Boháč J, Přikryl R, Sedlářová I (2012) Maturation of loess treated with variable lime admixture: pore space textural evolution and related phase changes. Appl Clay Sci 61:37-43

30. Monroy R, Zdravkovic L, Ridley A (2010) Evolution of microstructure in compacted London Clay during wetting and loading. Géotechnique 60(2):105-119

31. Nalbantoglu Z, Tuncer ER (2001) Compressibility and hydraulic conductivity of a chemically treated expansive clay. Can Geotech J 38:154-160

32. Ng CWW, Pang Y (2000) Experimental investigations of the soil-water characteristics of a volcanic soil. Can Geotech J 37:1252-1264

33. Ng CWW, Pang Y (2000) Influence of stress state on soil-water characteristics and slope stability. J Geotech Geoenviron Eng 126(2):157-166

34. Otter L (2011) The influence of suction changes on the stiffness of railway formation, Ph.D. thesis, University of Southampton 
35. Romero E, Vaunat J (2000) Retention curves of deformable clays. In: Tarantino A, Mancuso C (eds) Experimental evidence and theoretical approaches in unsaturated soils. Balkema, Rotterdam, pp 91-106

36. Romero E, Della Vecchia G, Jommi C (2011) An insight into the water retention properties of compacted clayey soils. Géotechnique 61(4):313-328

37. Russo G (2005) Water retention curves of lime stabilised soil. In: Tarantino A, Romero E, Cui YJ (eds) Advanced experimental unsaturated soil mechanics; proceedings of the international workshop on advanced experimental unsaturated soil mechanics, Experus 2005, Trento (I), 27-29 June 2005. Balkema, Rotterdam, pp 391-396

38. Salager S, Nuth M, Ferrari A, Laloui L (2013) Investigation into water retention behaviour of deformable soils. Can Geotech $\mathbf{J}$ 50:200-208

39. Sillers SW, Fredlund DG, Zakerzadeh N (2001) Mathematical attributes of some soil-water characteristic curve models. Geotech Geol Eng 19(3-4):243-283

40. Tarantino A (2009) A water retention model for deformable soils. Géotechnique 59(9):751-762

41. Tedesco DV, Russo G (2008) Time dependency of the water retention properties of a lime stabilised compacted soil. In: Toll DG, Augarde CE, Gallipoli D, Wheeler SJ (eds) Unsaturated soils: advances in geo-engineering, proceedings of the 1st European conference on unsaturated soils, E-UNSAT 2008, Durham, UK, July 2-4, 2008. CRC Press, London, pp 277-282

42. Tinjum JM, Benson CH (1997) Soil-water characteristic curves for compacted clays. J Geotech Geoenviron Eng 123(11):1060-1069

43. Toll DG (1995) A conceptual model for the drying and wetting of soil. In: Alonso EE, Delage P (eds) First international conference on unsaturated soils, Paris, vol 2, pp 805-810

44. van Genuchten MT (1980) A closed form equation for predicting the hydraulic conductivity of unsaturated soils. Soil Sci Soc Am J 44:892-898

45. Vanapalli SK, Pufahl DE, Fredlund DG (1999) The influence of soil structure and stress history on the soil-water characteristic of a compacted till. Géotechnique 49(2):143-159

46. Wang X, Benson CH (2004) Leak-free pressure plate extractor for measuring the soil water characteristic curve. ASTM Geotech Test J 27(2):163-172

47. Wang Q, Tang AM, Cui YJ, Delage P, Gatmiri B (2012) Experimental study on the swelling behaviour of bentonite/claystone mixture. Eng Geol 124(4):59-66

48. Zhang X, Mavroulidou M, Gunn MJ (2015) Mechanical properties and behaviour of a partially saturated lime-treated, high plasticity clay. Eng Geol 193:320-336 